Prepared in cooperation with the Missouri River Recovery Program

\title{
Development of Working Hypotheses Linking Management of the Missouri River to Population Dynamics of Scaphirhynchus albus (Pallid Sturgeon)
}

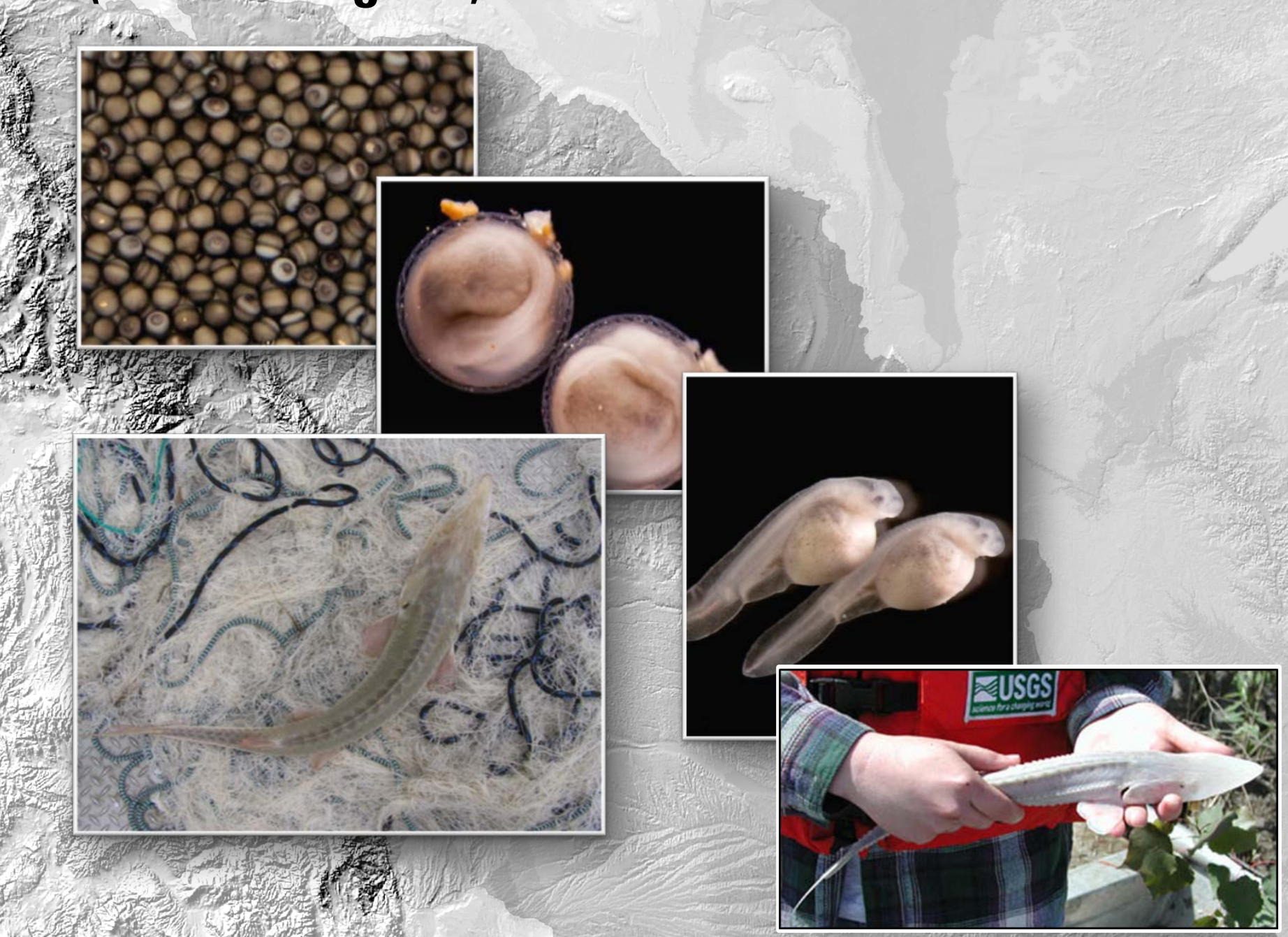

Open-File Report 2015-1236

U.S. Department of the Interior U.S. Geological Survey 
Cover photograph index:

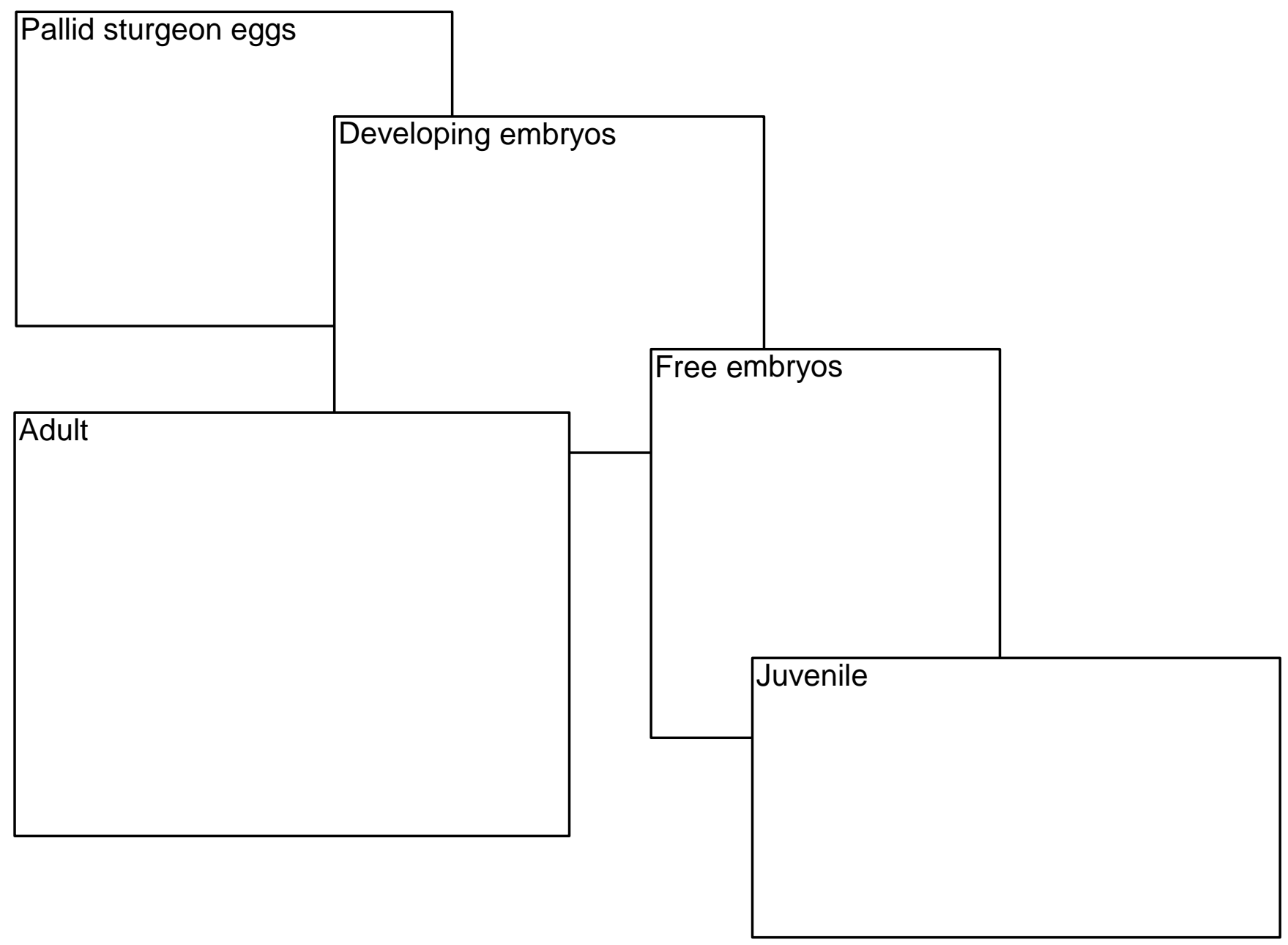

Background image: shaded relief map of the Missouri River drainage basin, US Geological Survey, EROS Data Center.

Photographs by U.S. Geological Survey personnel 


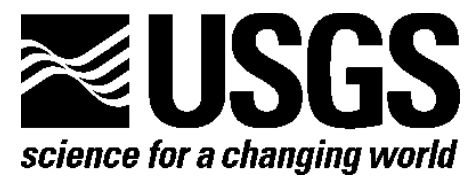

Prepared in cooperation with the U.S. Army Corps of Engineers, Missouri River Recovery Program

\section{Development of Working Hypotheses Linking Management of the Missouri River to Population Dynamics of Scaphirhynchus albus (Pallid Sturgeon)}

By Robert B. Jacobson, Michael J. Parsley, Mandy L. Annis, Michael E. Colvin, Timothy L. Welker, and Daniel A. James

Open-File Report 2015-1236

U.S. Department of the Interior

U.S. Geological Survey 


\section{U.S. Department of the Interior \\ SALLY JEWELL, Secretary}

\section{U.S. Geological Survey}

Suzette M. Kimball, Director

\section{U.S. Geological Survey, Reston, Virginia: 2016}

For more information on the USGS-the Federal source for science about the Earth, its natural and living resources, natural hazards, and the environment-visit http://www.usgs.gov/ or call 1-888-ASK-USGS (1-888-275-8747).

For an overview of USGS information products, including maps, imagery, and publications, visit http://www.usgs.gov/pubprod/.

Any use of trade, firm, or product names is for descriptive purposes only and does not imply endorsement by the U.S. Government.

Although this information product, for the most part, is in the public domain, it also may contain copyrighted materials as noted in the text. Permission to reproduce copyrighted items must be secured from the copyright owner.

Suggested citation:

Jacobson, R.B., Parsley, M.J., Annis, M.L., Colvin, M.E., Welker, T.L., and James, D.A., 2016, Development of working hypotheses linking management of the Missouri River to population dynamics of Scaphirhynchus albus (pallid sturgeon): U.S. Geological Survey Open-File Report 2015-1236, 33 p., http://dx.doi.org/10.3133/ofr20151236. 


\section{Contents}

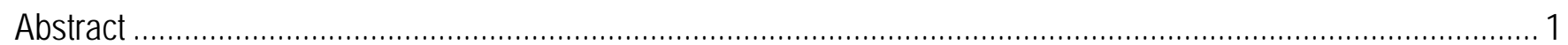

Introduction

Purpose and Scope ………

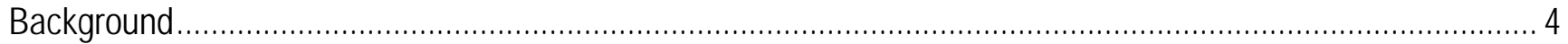

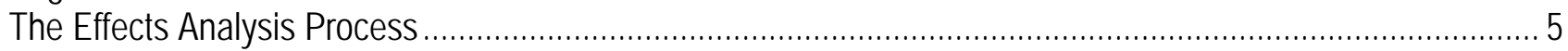

Hypotheses and the Missouri River Recovery Management Plan ............................................................ 6

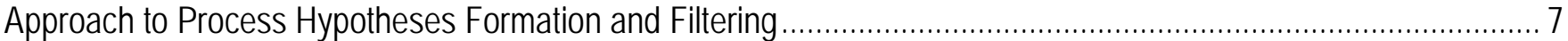

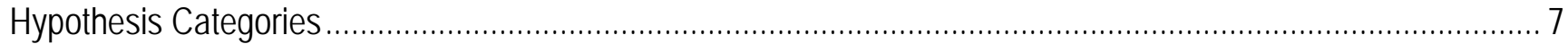

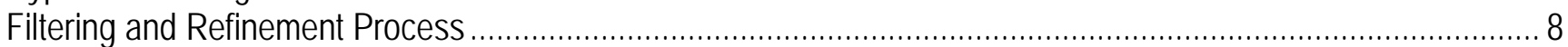

Working Hypotheses Linking Management of the Missouri River to Population Dynamics ..................................... 11

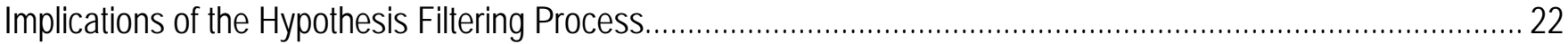

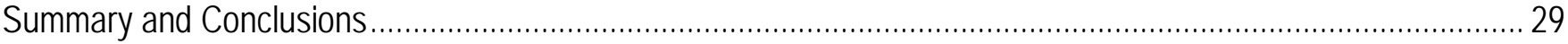

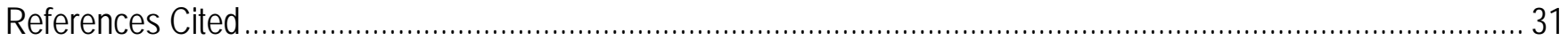

\section{Figures}

Figure 1. Components of the Missouri River Pallid Sturgeon Effects Analysis for Phases 1, 2, and 3 .

Figure 2. Missouri River Basin and locations of river segments that are part of the Missouri River Pallid Sturgeon Effects Analysis.

Figure 3. Diagram showing an example of a conceptual ecological model for life-stage components for the source of dominant working hypotheses (right side) and working management hypotheses (left side).

Figure 4. Graphs showing the results of the first survey of dominant working hypotheses. $A$, Response scores. $B$, No relevant knowledge.

Figure 5. Graphs showing the results of the second survey of dominant working hypotheses. $A$, Response scores.

$B$, No relevant knowledge.

Figure 6. Graphs showing the results of the survey of working management hypotheses, Upper Missouri River. A, Response scores. B, No relevant knowledge. GAPT refers to the Gavins Point Dam; DO, dissolved oxygen..

Figure 7. Graphs showing the results of the survey of working management hypotheses, Lower Missouri River. A, Response scores. B, No relevant knowledge.YSTN refers to the Yellowstone River and UPMOR refers to the Upper Missouri River; Lake Sak refers to Lake Sakakawea.

Figure 8. Cumulative growth in pallid sturgeon science peer-reviewed publications, 1992-2014 .......................... 28

\section{Tables}

Table 1. Categories of the hypotheses filtering process for the Missouri River Pallid Sturgeon Effects Analysis

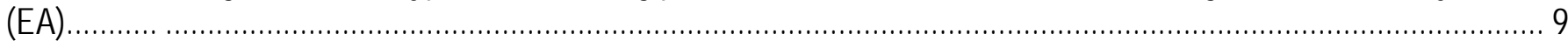

Table 2. Candidate dominant working hypotheses before first round of expert survey ........................................ 12

Table 3. Candidate dominant working hypotheses before second round of expert survey ..................................... 15

Table 4. Candidate working management hypotheses before third survey ……………………........................ 19

Table 5. Working set of management hypotheses after expert elicitation.......................................................... 23 


\section{Conversion Factors}

Inch/Pound to International System of Units

\begin{tabular}{|c|c|c|}
\hline Multiply & By & To obtain \\
\hline \multicolumn{3}{|c|}{ Length } \\
\hline mile (mi) & 1.609 & kilometer (km) \\
\hline \multicolumn{3}{|c|}{ Area } \\
\hline acre & 4,047 & square meter $\left(\mathrm{m}^{2}\right)$ \\
\hline acre & 0.4047 & hectare (ha) \\
\hline acre & 0.4047 & square hectometer $\left(\mathrm{hm}^{2}\right)$ \\
\hline acre & 0.004047 & square kilometer $\left(\mathrm{km}^{2}\right)$ \\
\hline \multicolumn{3}{|c|}{ Density } \\
\hline acres per mile & 0.2515 & hectares per kilometer $(\mathrm{km})$ \\
\hline
\end{tabular}

International System of Units to Inch/Pound

\begin{tabular}{lcl}
\hline & Multiply & To obtain \\
\hline & Length & \\
\hline kilometer $(\mathrm{km})$ & 0.6214 & mile (mi) \\
\hline & Area & \\
\hline hectare (ha) & 2.471 & acre \\
square kilometer $\left(\mathrm{km}^{2}\right)$ & 247.1 & acre \\
\hline
\end{tabular}

Temperature in degrees Celsius $\left({ }^{\circ} \mathrm{C}\right)$ may be converted to degrees Fahrenheit $\left({ }^{\circ} \mathrm{F}\right)$ as ${ }^{\circ} \mathrm{F}=\left(1.8 \times{ }^{\circ} \mathrm{C}\right)+32$.

Temperature in degrees Fahrenheit $\left({ }^{\circ} \mathrm{F}\right)$ may be converted to degrees Celsius $\left({ }^{\circ} \mathrm{C}\right)$ as ${ }^{\circ} \mathrm{C}=\left({ }^{\circ} \mathrm{F}-32\right) / 1.8$.

To communicate effectively with stakeholders, managers, and other scientists working on the Lower Missouri River, this report uses a mix of U.S. customary units and International System of Units (SI) units of measure.

\section{Datum}

Vertical coordinate information is referenced to the North American Vertical Datum of 1988 (NAVD 88).

Horizontal coordinate information is referenced to the World Geodetic System of 1984 (WGS 84). 


\title{
Development of Working Hypotheses Linking Management of the Missouri River to Population Dynamics of Scaphirhynchus albus (Pallid Sturgeon)
}

By Robert B. Jacobson, ${ }^{1}$ Michael J. Parsley, ${ }^{2}$ Mandy L. Annis, ${ }^{1}$ Michael E. Colvin, ${ }^{3}$ Timothy L. Welker, ${ }^{4}$ and Daniel A. James 5

\begin{abstract}
This report documents a process of filtering of hypotheses that relate Missouri River Scaphirhynchus albus (pallid sturgeon) population dynamics to management actions including flow alterations, channel reconfigurations, and pallid sturgeon population augmentation. The filtering process was a partnership among U.S. Geological Survey, U.S. Army Corps of Engineers, and U.S. Fish and Wildlife Service to contribute to the Missouri River Recovery Management Plan process. The objective of the filtering process was to produce a set of hypotheses with high relevance to pallid sturgeon population dynamics and decision making on the Missouri River. The Missouri River Pallid Sturgeon Effects Analysis team filtered hundreds of potential hypotheses implicit in conceptual ecological models to develop a set of 40 candidate dominant hypotheses that were identified by experts as being important in pallid sturgeon population dynamics. Using a modified Delphi process and additional expert opinion, the team reduced this set of hypotheses to 23 working dominant hypotheses. We then matched the 23 hypotheses with management actions that could influence the biotic outcomes, resulting in as many as 176 potential effects between management actions and pallid sturgeon in the Missouri River. This number was consolidated to a candidate set of 53 working management hypotheses because some management actions applied to multiple life stages of the pallid sturgeon. We used an additional round of expert surveys to identify a set of 30 working management hypotheses. Finally, the set of working management hypotheses was filtered by the U.S. Army Corps of Engineers, Missouri River Recovery Program for actions that were within the agency's authority and jurisdiction. This round resulted in a set of 21 hypotheses for initial modeling of linkages from management to pallid sturgeon population responses.
\end{abstract}

The initial set of candidate hypotheses provides a useful starting point for quantitative modeling and adaptive management of the river and species. We anticipate that hypotheses will change from the set of working management hypotheses as adaptive management progresses. More importantly,

${ }^{1}$ Columbia, Missouri.

${ }^{2}$ Cook, Washington, retired.

${ }^{3}$ Mississippi State University.

${ }^{4}$ U.S. Army Corps of Engineers.

${ }^{5}$ U.S. Fish and Wildlife Service. 
hypotheses that have been filtered out of our multistep process are still being considered. These filtered hypotheses are archived and if existing hypotheses are determined to be inadequate to explain observed population dynamics, new hypotheses can be created or filtered hypotheses can be reinstated.

\section{Introduction}

This report documents a systematic process by which hypotheses about the effects between management actions and Scaphirhynchus albus (pallid sturgeon) populations in the Missouri River were developed and prioritized. The objective of this process was to develop hypotheses that would define the scope and type of effort needed to develop quantitative models linking management actions to pallid sturgeon population dynamics. The process is a step in the Missouri River Pallid Sturgeon Effects Analysis (EA), carried out as a partnership among U.S. Geological Survey USGS), U.S. Army Corps of Engineers (USACE), and U.S. Fish and Wildlife Service (USFWS) as part of the Missouri River Recovery Management Plan.

The EA team is charged with a multistep process, resulting in four supporting reports (fig. 1):

- Develop Conceptual Ecological Models (CEMs) to document and illustrate driver-stressorresponse ecological relations for Missouri River pallid sturgeon (Jacobson and others, 2015b) .

- Compile, assess, and document available information and modeling resources that can be used to understand historical and future changes of pallid sturgeon populations (Jacobson and others, 2015a).

- Develop a filtered set of hypotheses to depict relations in the CEMs. The process of hypothesis formulation and filtering is documented in this report.

- Compile multiple lines of evidence by using the best available science to assess working management hypotheses. This will be the next report in the series and will include the best available combinations of qualitative and quantitative models, theoretical and empirical data, and expert opinion.

In a broader context, the EA process has three phases. The four reports are considered phase 1, and provide the scientific background needed to serve as a foundation for planning and adaptive management. Phase 2 will include incorporation of that foundation into design of an adaptive management process for pallid sturgeon in Missouri River management. Phase 3 is implementation of management actions under adaptive management.

The documents produced by the EA team are intended to inform Missouri River Recovery Program (MRRP) decisions about how to best manage the Missouri River and its resources to meet species-management objectives. For pallid sturgeon in the Missouri River, the species-management objective is to "Avoid jeopardizing the continued existence of the pallid sturgeon from U.S. Army Corps of Engineers actions on the Missouri River" (U.S. Fish and Wildlife Service, written commun., 2013). The USFWS notes that this objective is consistent with species recovery goals (U.S. Fish and Wildlife Service, 2014) but is specific to Missouri River management actions.

The CEM and quantitative model framework developed through the EA are intended to form part of the framework for future adaptive management of the Missouri River. We anticipate that the plan will include an ongoing assessment process similar to the EA, whereby new information from monitoring, assessment, and research efforts will be used to improve management actions in the future. An important part of this effort will be the option to refer previously developed CEMs if the need arises to provide and filter new hypotheses to explain observed changes in pallid sturgeon populations. 


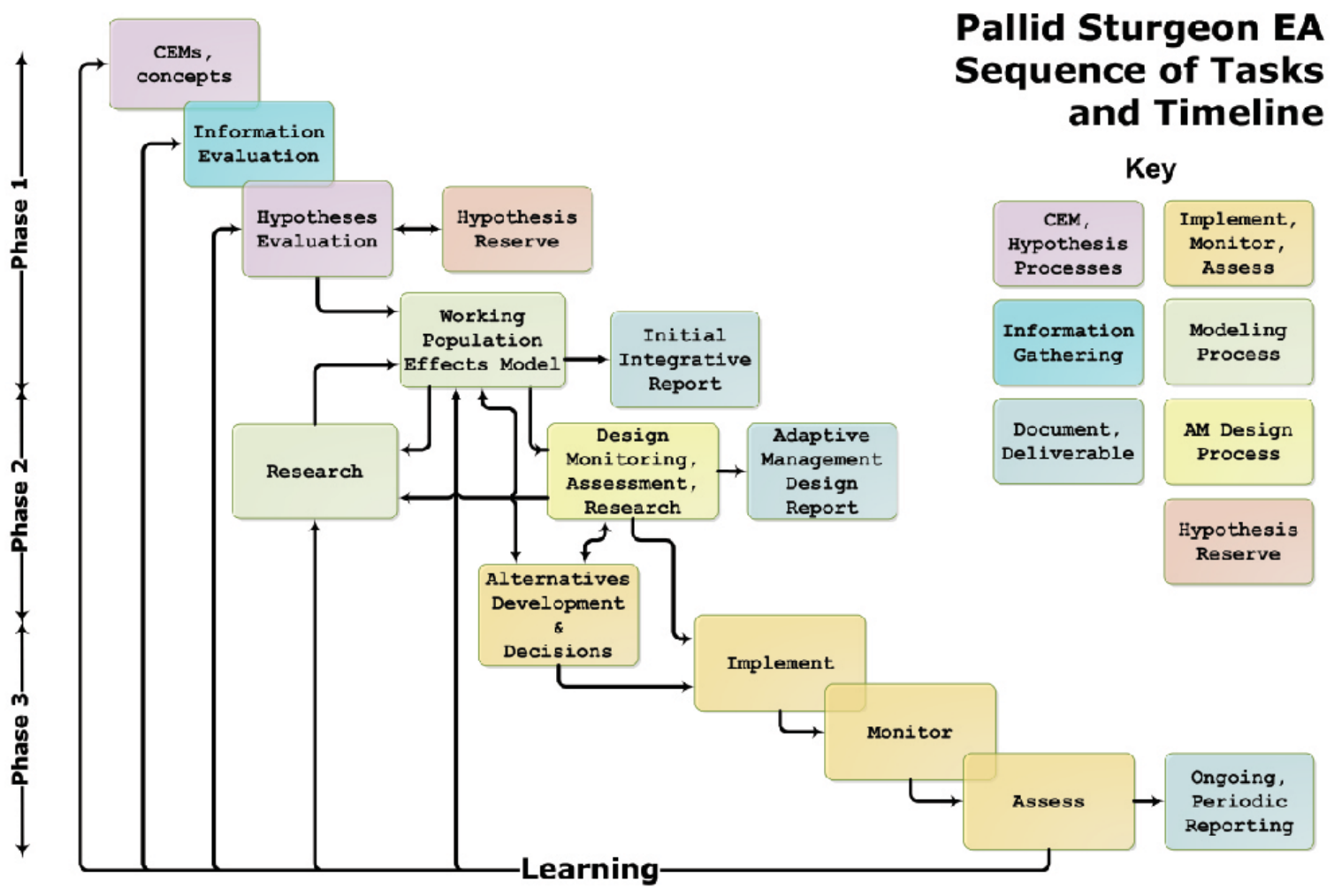

Figure 1. Components of the Missouri River Pallid Sturgeon Effects Analysis for Phases 1, 2, and 3.

\section{Purpose and Scope}

The purpose of this report is to document a process by which working hypotheses were developed to link management of the Missouri River to population dynamics of pallid sturgeon. This report is the third in a series intended to document the EA process. The process generally follows the concepts of effects analysis as outlined in an article by Murphy and Weiland (2011), although with some deviation from the ideal Murphy and Weiland process as a result of practical considerations.

This report documents the process of categorizing, prioritizing, and documenting a working set of hypotheses to link management actions to pallid sturgeon population dynamics. The process has involved multiple sequential steps to organize the hypotheses and evaluate them using expert opinion and available scientific information.

The objective of the hypothesis development process has been to provide initial scope and structure to subsequent steps in the EA process. In particular, prioritized hypotheses are needed to constrain the scope of quantitative modeling because it would be impossible to model the large number of potential hypothetical influences that emanated from the CEMs. The priority hypotheses sought in this process are meant to be broadly articulated because they will be used as the foundation for sequential testing and refinement of hypotheses, and development of new hypotheses, as quantitative understanding evolves. 


\section{Background}

The pallid sturgeon is an endangered, benthic fish endemic to the turbid Missouri and Mississippi Rivers and the lower parts of larger tributaries. The pallid sturgeon was listed as endangered under the U.S. Endangered Species Act of 1973 (16 U.S.C. ch. 35 § 1531) in 1990 (U.S. Fish and Wildlife Service, 1993). Numerous factors have likely contributed to the species decline. The "Pallid Sturgeon Recovery Plan" (U.S. Fish and Wildlife Service, 1993) and the "Revised Pallid Sturgeon Recovery Plan” (U.S. Fish and Wildlife Service, 2014) reported that engineered modifications to the Missouri River have been the major factors in species decline, with potential contributions from commercial harvesting, and industrial and agricultural contaminants. In 2000, the USFWS published the "2000 Biological Opinion," (U.S. Fish and Wildlife Service, 2000a) finding that USACE operations of the Missouri River were likely to jeopardize the existence of the pallid sturgeon through fragmentation of habitats, limiting migration to spawning and feeding areas, altering conditions and flows in spawning areas, reducing food sources through limited productivity of those food sources, and diminishing rearing habitat for age-0 sturgeon. The "Biological Opinion" and a 2003 amendment defined elements of a reasonable and prudent alternative (RPA) to avoid jeopardy to these Missouri River populations (U.S. Fish and Wildlife Service, 2000a, 2003). The pallid sturgeon RPA elements include (among others) implementation of adaptive management, monitoring, and research, in addition to restoration of 20-30 acres per mile (5-7 ha/ $\mathrm{km}$ ) of shallow-water habitat (SWH) downstream of Gavins Point Dam (fig. 2), increased pallid sturgeon propagation and augmentation, and implementation of spring rises and summer low flows in the flow regimes from Fort Peck and Gavins Point Dams.

Large-scale restoration of Missouri River channel and flood-plain habitats date from the Missouri River Bank Stabilization and Navigation Project Fish and Wildlife Mitigation Program (Mitigation Program), which was authorized in the Water Resources Development Act of 1986 (33 USC 2309a; WRDA 1986), 5 years after completion of the Bank Stabilization and Navigation Program (BSNP) (National Research Council Committee on Missouri River Ecosystem Science, 2002). The Mitigation Program was intended originally to mitigate for habitat losses due to the BSNP, with a goal of restoring 166,750 acres of channel, sandbar, and meander-belt habitat, approximately 32 percent of the estimated lost habitat (U.S. Army Corps of Engineers, 1981). The goals for compliance with the amended biological opinion and for the Mitigation Program were formally collected into the MRRP in the Water Resources Development Act of 2007 (Public Law 110-114; WRDA 2007). WRDA 2007 also authorized mitigation projects along the main-stem Missouri River in the upper part of the river that includes Montana, North Dakota, Nebraska, and South Dakota, as well as restoration projects in the Yellowstone River and its tributaries in Montana and North Dakota. WRDA 2007 further authorized use of USACE funding to assist the Bureau of Reclamation with planning and construction of fish passage around the Lower Yellowstone Intake Diversion Dam (Intake Dam, fig. 2).

Implementation of fish, wildlife, and habitat restoration activities on the Missouri River has been guided by principles of adaptive management since adoption of the "2000 Biological Opinion” (U.S. Fish and Wildlife Service, 2000b) and the 2001 Master Manual revision (U.S. Army Corps of Engineers, 2001). Adaptive management was adopted more formally with creation of the Missouri River Recovery Implementation Committee (MRRIC), an advisory group to the USACE authorized in WRDA 2007. MRRIC includes committees that are closely aligned with the practice of adaptive management: the Science and Adaptive Management (SAM) work group and the Independent Science Advisory Panel (ISAP). 


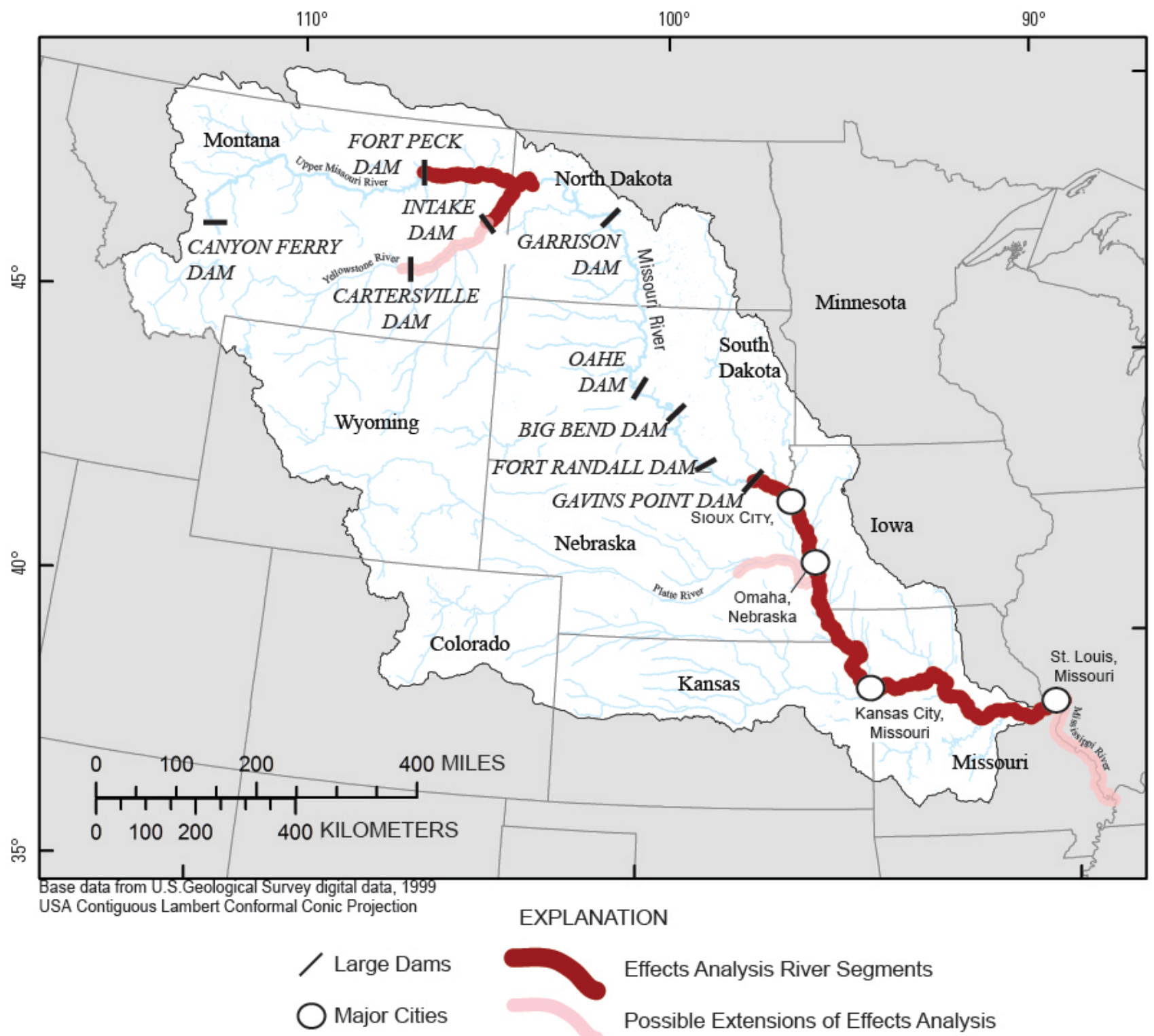

Figure 2. Missouri River Basin and locations of river segments that are part of the Missouri River Pallid Sturgeon Effects Analysis.

Emphasis on construction of conceptual ecological models and implementation of effects analyses were prominent recommendations of the ISAP to promote robust adaptive management of the river and its imperiled species (Doyle and others, 2011).

\section{The Effects Analysis Process}

The EA process is following the recommendation of Murphy and Weiland (2011), with minor deviation due to practical considerations. The EA process is essentially an attempt to formalize understanding of how the river system works in relation to pallid sturgeon population dynamics, how the river and population have been altered, and how future management actions may affect the population. The EA process is covered in a series of four reports. 
The first report in the series documents development of conceptual ecological models (CEMs) for the pallid sturgeon in the Missouri River (Jacobson and others, 2015b). Two levels of CEMs were presented. A population-level CEM illustrated a life-stage based population structure, indicating how population augmentation factors could affect population dynamics and how life-stage specific factors could affect survival at each life-stage transition. Life-stage component-level CEMs were developed with a hierarchical structure to illustrate how independent geological and climatic factors, and management actions, could propagate through to affect habitat, ecological conditions, and pallid sturgeon survival (or life-stage transition) probabilities. The CEM development process produced many potential relations among factors and biotic responses, which were classified with relative uncertainty and relative influence. These "global" hypotheses were the starting place for the process documented in this report.

The second report in the series (Jacobson and others, 2015a) is a compilation of relevant data sources for informing pallid sturgeon science on the Missouri River. This document describes the current state of the science, documents the quantity of data available in various sources, and evaluates the applicability of available scientific information to the EA process.

The present report documents the process of filtering hypotheses to arrive at a working set to serve as the start of an adaptive management process. The fourth report in the series is an integration of information and quantitative models relating to the working set of hypotheses documented in this report.

\section{Hypotheses and the Missouri River Recovery Management Plan}

The working set of hypotheses documented in this report is not intended to be the exclusive set of all hypotheses about factors affecting pallid sturgeon population dynamics. Instead, the working set of hypotheses is intended to be a selection that is relevant to population dynamics and to decision making based on the present state of science. Relevance to decision making, in the short term, includes being within USACE jurisdictions and authorities.

The working set of management hypotheses identifies types of actions, but most management action types for the Missouri River would involve a range of alterations. For example, a working management hypothesis may identify naturalization of the flow regime, and this may then become the basis for quantitative modeling of how flow regime affects pallid sturgeon population dynamics. The term naturalization is used here to denote using the natural flow regime as a template for flow management, but manipulating elements (for example, magnitude, duration, or timing of events) to a socially acceptable level (Rhoads and others, 1999). Identification of the biologically effective and socially acceptable range of alteration within the flow naturalization action is a subsequent step that will be addressed in trade-offs with human considerations during structured decision making. More importantly, identification of management hypotheses should not limit planning for alternatives under the National Environmental Protection Act of 1969 (42 USC § 4321; NEPA) because those alternatives would, in most cases, address specific ranges of alterations within the management hypotheses actions. Most importantly, under the umbrella of adaptive management, there should be no impediment to revisiting previously filtered hypotheses or developing new hypotheses if ongoing assessments indicate that the present working set is insufficient to explain observed population dynamics.

Selection of the working set has also been affected by practical consideration of its utility to the MRRP Management Plan (MRRMP). The MRRMP is a three-year planning process to develop an environmental impact statement (EIS) for the continuation of the MRRP. The USACE determined that CEMs, hypotheses, and quantitative models developed under the EA would be useful to the MRRMP, and so the decision was made to compress EA activities into the first year of the MRRMP process. This 
is a considerable challenge to the EA because the ideal effects analysis outlined in Murphy and Weiland (2011) is clearly a multi-year process for a system as broad and complex as the Missouri River. The working solution to this challenge has been to pursue a compressed EA process in the short term (Phase 1, fig. 1) to provide the MRRMP with needed information in the first year. Phase 1 is intended to be followed by development of an adaptive management plan which will include ongoing evaluation of information and hypotheses (Phase 2). Phase 2 may serve to broaden the set of hypotheses considered as well as contributing to design and implementation of research, monitoring, and assessment under adaptive management (fig. 1).

The MRRMP is being designed with adaptive management as a core concept. Because the MRRMP Adaptive Management Plan is being developed in parallel with the EA, it is not possible to cite the document here. However, early drafts emphasize the role of continued learning and collaborative decision making in the future of Missouri River management (A. Quinn, USACE, written commun., 2015). EA documents like the present report and the CEM report (Jacobson and others, 2015b) make it abundantly clear that management decisions relating to pallid sturgeon jeopardy are made within a framework of substantial uncertainty. Rigorous application of methods of adaptive management (Phase 3) seems to be a promising strategy to continue with decision making in the face of this uncertainty.

The geographic scope of the EA is the Upper Missouri River main stem from Fort Peck Dam to the headwaters of Lake Sakakawea, the Yellowstone River upstream from the confluence with the Upper Missouri River for an unspecified distance, the Lower Missouri River main stem from Gavins Point Dam to confluence with the Mississippi River at St. Louis, tributaries used by pallid sturgeon, and an unspecified distance downstream in the Mississippi River (fig. 2). The geographic scope is constrained, in part, by decision making authority of the USACE and in part by present understanding of the geographic distribution of pallid sturgeon. At present, the reservoir and inter-reservoir reaches from the headwaters of Lake Sakakawea to Gavins Point Dam would not be considered explicitly in the EA. The potential for inter-reservoir reaches with clear, cold water and hydropeaking releases to contribute to pallid sturgeon recovery was considered low but may be usefully considered in Phase 2. The geographic scope also includes processes and conditions acting in Missouri River tributaries and the Mississippi River if those processes and conditions would likely affect population processes in the Missouri River.

\section{Approach to Process Hypotheses Formation and Filtering}

The approach for this study was mostly based on a similar process aimed at recovery of Acipenser transmontanus (white sturgeon) in the Upper Columbia River (Gregory and Long, 2008). The study of the white sturgeon had many of the same issues as the pallid sturgeon found in the Missouri River, with the primary similarity being landscape-level anthropogenic alterations that affected several aspects of the species life-history requirements. In both cases, linkages between requisite management actions and species' responses to those actions had substantial uncertainties. An important difference was the time frame- - the hypothesis filtering process on the Columbia River took 18 months, whereas only 8 months were available for our process along the Missouri River.

\section{Hypothesis Categories}

The starting point for development of the working set of management hypotheses was the lifestage component CEMs described in Jacobson and others (2015b). From those diagrams we 
progressively filtered and refined hypotheses according to a four-part categorization (table 1). All of the possible pathways depicted in the CEMs comprise our global hypotheses, a broad list of hypotheses that have a possible role in explaining decline of the pallid sturgeon. The global hypotheses were filtered to provide a candidate list of dominant working hypotheses based on experts' survey responses. This resulted in the biologically based dominant working hypotheses. The dominant working hypotheses represent a scientific perspective of factors that contribute to population dynamics of the pallid sturgeon in the Missouri River. The list of dominant working hypotheses is meant to include plausible, biologically relevant hypotheses without regard to specific management or mitigation actions.

The dominant working hypotheses have been developed from the right side of the component CEMs (fig. 3), and present the hypotheses as combinations of factors that contribute to high mortality at each life stage. These hypotheses indicate factors and processes that are responsible for decline, but do not address management actions that would reverse or mitigate decline by increasing survival of the pallid sturgeon. Mitigation is addressed through another category of hypotheses, working management hypotheses (table 1), which integrate management actions on the left side of the CEMs (fig. 3) with the biologically based, dominant working hypotheses on the right side. Working management hypotheses consider actions that could aid in species recovery without testing if the species fall within USACE jurisdiction. Because multiple management hypotheses may affect similar biological responses, more working management hypotheses than dominant working hypotheses were produced. Working management hypotheses will also likely be more spatially explicit as some management options would be more effective in some areas compared to other areas.

The final step in the hypothesis prioritization process involved filtering the working management hypotheses for those that fall within USACE authorities and jurisdictions. This step defined a set of initially modeled hypotheses that will guide modeling by the EA team. The initially modeled hypotheses (table 1) provide a scope for the quantitative modeling for the MRRMP in Phase 1 (fig. 1). However, filtering the working management hypotheses to focus on USACE authorities and jurisdictions will not necessarily address all factors that potentially limit population growth in pallid sturgeon. Ongoing effects analyses under adaptive management in Phases 2 and 3, after the initial effort under the MRRMP, may address hypotheses outside of USACE authorities; for example, hypotheses that address the effects of municipal wastewater exposure to pallid sturgeon.

\section{Filtering and Refinement Process}

The initial approach to address the many combinations of ecological characteristics (fig. 3) (boxes) and influences (arrows) was to consider the primary biotic responses on the right-hand side of the CEM diagrams (fig. 3), which were categorized into growth and condition, direct mortality, and reproductive performance. These biotic characteristics are related to survival of the particular life stage (or production of viable gametes from adults), and thus, were considered biologically influential to population dynamics. As a first step, the EA team selected those pathways that experts had depicted as important and certain to develop a candidate list of working dominant hypotheses. The candidate set of working dominant hypotheses were written interpretations of the important pathways on the right side of the CEMs (fig. 3, table 2); these hypotheses were articulated as conditions that would promote (alone or with other effects) substantial mortality. 
Table 1. Categories of the hypotheses filtering process for the Missouri River Pallid Sturgeon Effects Analysis (EA)

[USACE refers to the U.S. Army Corps of Engineers]

\begin{tabular}{cc}
\hline Category & Description \\
\hline Global........................ & $\begin{array}{c}\text { Set of possible, biologically important hypotheses, relevant to population dynamics. } \\
\text { Derived from conceptual ecological models. }\end{array}$ \\
Dominant Working...... & $\begin{array}{r}\text { Set of plausible, biologically important hypotheses, relevant to population dynamics. } \\
\text { Derived from importance values in conceptual ecological model, scored by expert } \\
\text { elicitation survey. }\end{array}$ \\
Working Management.. & $\begin{array}{l}\text { Set of management hypotheses linking management actions to working dominant } \\
\text { hypotheses. Derived from pathways identified in conceptual ecological models and } \\
\text { matched to working dominant hypotheses. Scored by expert elicitation survey. }\end{array}$ \\
Initially Modelled......... & $\begin{array}{l}\text { Subset of working management hypotheses determined by USACE to be within } \\
\text { jurisdiction and applicable authorities, and therefore selected for modeling in EA } \\
\text { Phase } 1 .\end{array}$
\end{tabular}

We engaged 21 experts in a modified Delphi process, a structured communication technique, originally developed as a systematic, interactive forecasting method that relies on a panel of experts (Normand and others, 1998), to prompt expert opinion on prioritization of dominant working hypotheses. The experts were selected based on knowledge of pallid sturgeon science, or a strong understanding of Missouri River abiotic processes, or both. The experts represented Federal and State agencies, universities, and the private sector from throughout the Missouri River Basin. The experts offered professional opinions and were not asked to develop consensus or recommendations. The modified Delphi process consisted of a Web-based survey in which experts were asked to score the importance of the hypotheses from low to high, including a neutral response and the option to indicate that they did not have sufficient relevant knowledge to score the dominant working hypotheses (fig. 4). We evaluated the results of the survey and presented the information during a workshop, March 11, 2014, where hypotheses with wide variance in score were discussed (fig. 4). Subsequent to the workshop, the experts participated in an additional survey with the same hypotheses, somewhat differently stated, and a few additional hypotheses were then introduced. The results were also evaluated and hypotheses with medians scoring higher than neutral (fig. 5) were retained as working dominant hypotheses for the next step of the filtering and refinement process.

The working management hypotheses are statements about the linkage between management actions and population dynamics, with a focus on actions that would mitigate population decline. Hence, working management hypotheses are based on dominant working hypotheses as targets, but may include multiple pathways for each dominant hypothesis. The EA team matched the working dominant hypotheses with potential management actions (left side of CEMs, fig. 3) based on relations in the CEMs. Because of the multiple pathways, this process yielded more hypotheses, but the number was subsequently narrowed by combining management actions that affected multiple-life stages of the pallid sturgeon. The team used these hypothesis statements in a second round of a modified Delphi process that elicited input from 25 experts from throughout the Missouri River Basin, representing a wide range of expertise from various government, academic and private sectors. Twenty-two individuals responded 


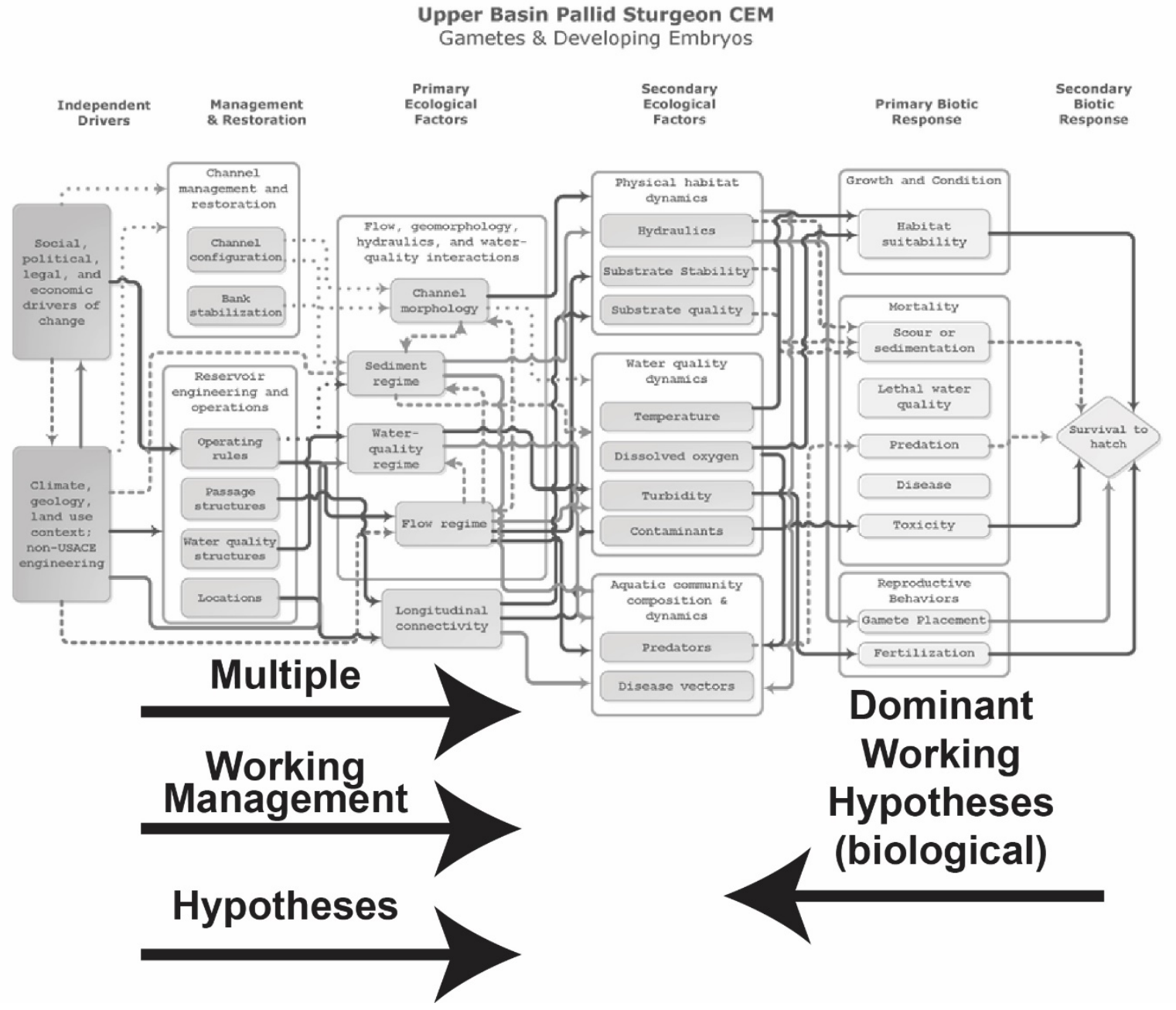

Figure 3. Diagram showing an example of a conceptual ecological model for life-stage components for the source of dominant working hypotheses (right side) and working management hypotheses (left side).

to the survey, and the results were quantified and analyzed. The hypotheses with median scores higher than neutral were retained, resulting in the set of working management hypotheses.

As a final step in Phase 1 prioritization, the working management hypotheses were submitted to the USACE and USFWS for comment and agreement. Based on criteria related to legal authorities and jurisdiction, the agencies indicated which hypotheses were not relevant to the present decision-making process. These decisions were conservative in the sense that there was emphasis on retaining a broad set of hypotheses to be reviewed in the structured decision-making process. 


\section{Working Hypotheses Linking Management of the Missouri River to Population Dynamics}

Extraction of hypotheses relating primary biotic responses (growth, condition, mortality, and reproduction) to survival resulted in a list of 40 candidate dominant hypotheses (table 2). The first round of survey resulted in a substantial range of variability among and within hypotheses (fig. 4). The first round of survey also allowed for suggestions for new hypotheses, which were discussed at the March 11, 2014 workshop. One of the points discussed during the workshop was the need for separate hypotheses for the Yellowstone River from those for the Upper Missouri River. Based on the workshop discussion, the EA team added nine hypotheses, which were submitted for the second round of survey (table 3). The second round resulted in remarkably similar results (fig. 5). Based on the criterion of median scores above neutral, we selected 23 hypotheses as the set of dominant working hypotheses (table 3).

Matching potential management actions (left side of CEMs, fig. 3), with each hypothesis in the working set, resulted in 176 potential hypothesis combinations because more than one management action could be associated with most of the dominant working hypotheses. However, in many cases, a single management action could also affect multiple-life stages, which could therefore be combined. This possibility allowed the total number of candidate management hypotheses to be reduced to 53 (table 4). Although only one expert survey was possible in the time available, the strong consistency in the two rounds of survey for the dominant working hypotheses indicate that the results would be unlikely to change much with a subsequent rounds (figs. 6 and 7). Based on the criterion of selecting hypotheses that have medians ranking above neutral, 30 working management hypotheses were selected to move forward (table 5).

Of the 30 working management hypotheses, 21 remained for initial modeling after the USACE and the USFWS agreed about authorities and jurisdictions. Hypotheses that will not be modeled during Phase 1 include the following actions:

- Removal of Fort Peck Dam. USACE does not have authority to remove the dam.

- Removal of Intake Dam, removal or construction of passage at Cartersville Dam (Yellowstone River). Removal of Intake Dam was not considered relevant to model at this time because construction of a passage system had already been approved and design and construction were in progress. The USACE determined that it was outside of their authority to remove or create passage at Cartersville.

- Regulation of agricultural and urban runoff to decrease endocrine-disrupting chemical exposure. The actions are outside of the USACE authority.

- Flow management on the Platte River to encourage spawning. The action is outside of the USACE authority.

The decision to remove hypotheses from consideration during Phase 1 is intended to focus efforts on modeling that will be relevant to decisions that need to be made under the MRRMP. Any hypothesis that is removed at this step - or any other step in the process - is available in later phases as needed to explain observed pallid sturgeon population changes. Processes to reexamine the reserved hypotheses will be an integral part of ongoing adaptive management of 
Table 2. Candidate dominant working hypotheses before first round of expert survey

[Key for labels: A, Adult; E, Embryo; F, Free embryo; L (first position), Larvae (exogenously feeding); J, Juvenile; U, Upper River; L (second position), Lower River. For this survey the Yellowstone and Upper Missouri Rivers were combined as Upper River]

\begin{tabular}{|c|c|c|}
\hline Number & Label & Hypothesis Statement \\
\hline 1 & AU1a & $\begin{array}{l}\text { Barriers to upstream migration prevent access to functional spawning sites with supportive } \\
\text { hydraulics and substrate, thereby decreasing probability of producing viable gametes. }\end{array}$ \\
\hline 2 & AU1b & $\begin{array}{l}\text { Hydrology-related events are inadequate to cue aggregation of reproductive adults, thereby } \\
\text { decreasing probability of mates to find one another. }\end{array}$ \\
\hline 3 & AU2a & Take of prespawn adults through poaching or other mechanisms has increased direct mortality. \\
\hline 4 & AU3a & $\begin{array}{l}\text { Population augmentation has increased numbers of conspecifics, increasing competition for } \\
\text { food resources in a fragmented system with decreased productivity, thereby decreasing } \\
\text { growth, condition, and fecundity. }\end{array}$ \\
\hline 5 & AL1a & $\begin{array}{l}\text { Habitat alterations have decreased separation of reproductive shovelnose and pallid sturgeon in } \\
\text { space and time, thereby increasing hybridization. }\end{array}$ \\
\hline 6 & AL1b & $\begin{array}{l}\text { Habitat alterations have decreased availability of functional spawning habitat while also } \\
\text { increasing availability of attractive, sub-optimal spawning habitat, thereby decreasing } \\
\text { probability of mates finding one another. }\end{array}$ \\
\hline 7 & AL1c & $\begin{array}{l}\text { Hydrology-related events are inadequate to cue aggregation of reproductive adults, thereby } \\
\text { decreasing probability of mates to find one another. }\end{array}$ \\
\hline 8 & AL2a & $\begin{array}{l}\text { Channelization and changes in flow regime have decreased food availability which results in } \\
\text { decreased growth, condition, and fecundity. }\end{array}$ \\
\hline 9 & AL2b & $\begin{array}{l}\text { Channelization and changes in flow regime have increased velocities, decreased habitat } \\
\text { suitability and complexity, resulting in decreased growth, condition, and fecundity. }\end{array}$ \\
\hline 10 & EU1a & $\begin{array}{l}\text { Hypolimnetic releases of cold water have increased embryo incubation time which results in } \\
\text { increased predation prior to hatch. }\end{array}$ \\
\hline 11 & EU1b & Decreased turbidity has increased efficacy of predators and predation prior to hatch. \\
\hline 12 & EU1c & Increased numbers of predators have increased predation prior to hatch. \\
\hline 13 & EL1a & Decreased turbidity has increased efficacy of predators and predation prior to hatch. \\
\hline 14 & EL1b & Increased numbers of introduced or invasive predators have increased predation prior to hatch. \\
\hline 15 & EL1c & $\begin{array}{l}\text { Channelization and changed flow regimes have increased scour and sediment deposition in } \\
\text { embryo incubation areas resulting in increases in direct mortality of developing embryos by } \\
\text { detachment, entrainment, or sedimentation (by crushing or smothering). }\end{array}$ \\
\hline 16 & FU1a & $\begin{array}{l}\text { Hypolimnetic releases of cold water have increased embryo development time which results in } \\
\text { increased predation prior to settling. }\end{array}$ \\
\hline 17 & FU1b & Decreased turbidity has increased efficacy of predators and predation prior to settling. \\
\hline 18 & FU1c & Increased numbers of predators has increased predation prior to settling. \\
\hline 19 & FU1d & $\begin{array}{l}\text { Barriers to upstream migration limit available downstream dispersal distance such that } \\
\text { dispersing free embryos settle in habitats that are not suitable for first feeding, thereby } \\
\text { increasing direct mortality. }\end{array}$ \\
\hline 20 & FU1e & $\begin{array}{l}\text { Barriers to upstream migration limit available downstream dispersal distance such that } \\
\text { dispersing free embryos settle in anoxic headwaters of downstream reservoirs increasing } \\
\text { direct mortality. }\end{array}$ \\
\hline 21 & FU2a & $\begin{array}{l}\text { Changes in flow regime, water quality, and(or) local habitat in settling areas have decreased the } \\
\text { prey base for first-feeding, decreasing growth, condition, and survival. }\end{array}$ \\
\hline 22 & FL1a & $\begin{array}{l}\text { Channelization has decreased post-hatch refugia in substrate interstices resulting in increased } \\
\text { direct mortality from predation. }\end{array}$ \\
\hline 23 & FL1b & $\begin{array}{l}\text { Reservoirs have decreased turbidity, resulting in increased efficacy of predators and increased } \\
\text { direct mortality from predation. }\end{array}$ \\
\hline 24 & FL1c & $\begin{array}{l}\text { Channelization has decreased suitable hydraulics to intercept and retain drifting free embryos, } \\
\text { resulting in increased direct mortality by starvation, inability to transition to first feeding. }\end{array}$ \\
\hline
\end{tabular}


Table 2. Candidate working dominant hypotheses before first round of expert survey - Continued

\begin{tabular}{|c|c|c|}
\hline Number & Label & Hypothesis Statement \\
\hline 25 & FL2a & $\begin{array}{l}\text { Channelization has decreased supportive habitat conditions for first feeding (increased } \\
\text { velocities, lack of habitat complexity) decreasing growth, condition, and survival. }\end{array}$ \\
\hline 26 & FL2b & $\begin{array}{l}\text { Changes in flow regime, water quality, and(or) channel complexity in settling areas result in } \\
\text { lack of suitable food for first feeding and decreases to growth, condition, and survival. }\end{array}$ \\
\hline 27 & LU1a & $\begin{array}{l}\text { Reservoirs have decreased turbidity, resulting in increased efficacy of predators and increased } \\
\text { direct mortality from predation. }\end{array}$ \\
\hline 28 & LU1c & $\begin{array}{l}\text { Reservoirs have created anoxic conditions in headwaters where many free embryos settle, } \\
\text { resulting in increased direct mortality. }\end{array}$ \\
\hline 29 & LU2a & $\begin{array}{l}\text { In areas upstream of reservoir headwaters, increased summer reservoir releases result in } \\
\text { increased velocities, decreases in supportive habitat, and decreases in growth, condition, and } \\
\text { survival. }\end{array}$ \\
\hline 30 & LU2b & $\begin{array}{l}\text { Changes in flow regime have decreased productivity of suitable foods, decreasing growth, } \\
\text { condition, and survival. }\end{array}$ \\
\hline 31 & LL1a & $\begin{array}{l}\text { Reservoirs have decreased turbidity, resulting in increased efficacy of predators and increased } \\
\text { direct mortality from predation. }\end{array}$ \\
\hline 32 & LL1b & Increased numbers of introduced or invasive predators increase predation \\
\hline 33 & LL1c & $\begin{array}{l}\text { Changes in flow regime and channelization have resulted in increased quality of physical } \\
\text { habitat for predators, resulting in increased predation. }\end{array}$ \\
\hline 34 & LL2a & $\begin{array}{l}\text { Changes in flow regime and channelization have resulted in increased velocities, decrease in } \\
\text { supportive channel complexity, and decreases in growth, condition, and survival. }\end{array}$ \\
\hline 35 & LL2b & $\begin{array}{l}\text { Changes in flow regime and channelization have resulted in decreased productivity of suitable } \\
\text { food, decreasing growth, condition, and survival. }\end{array}$ \\
\hline 36 & JU1a & $\begin{array}{l}\text { Reservoir releases have altered flow and temperature regimes, increasing bioenergetic demands } \\
\text { and decreasing growth, condition, and survival. }\end{array}$ \\
\hline 37 & JU1b & $\begin{array}{l}\text { Reservoir releases have altered flow and temperature regimes, decreasing productivity and food } \\
\text { availability, and resulting in decreases in growth, condition, and survival. }\end{array}$ \\
\hline 38 & JU1C & $\begin{array}{l}\text { Population augmentation has increased numbers of conspecifics, increasing competition for } \\
\text { food resources in a fragmented system with decreased productivity, thereby decreasing } \\
\text { growth, condition, and survival. }\end{array}$ \\
\hline 39 & JL1a & $\begin{array}{l}\text { Reservoir releases have decreased flow variation, resulting in decreased productivity and food } \\
\text { availability, and decreases in growth, condition, and survival. }\end{array}$ \\
\hline 40 & JL1b & $\begin{array}{l}\text { Channelization has decreased channel complexity, resulting in decreased productivity and food } \\
\text { availability, and decreases in growth, condition, and survival. }\end{array}$ \\
\hline
\end{tabular}



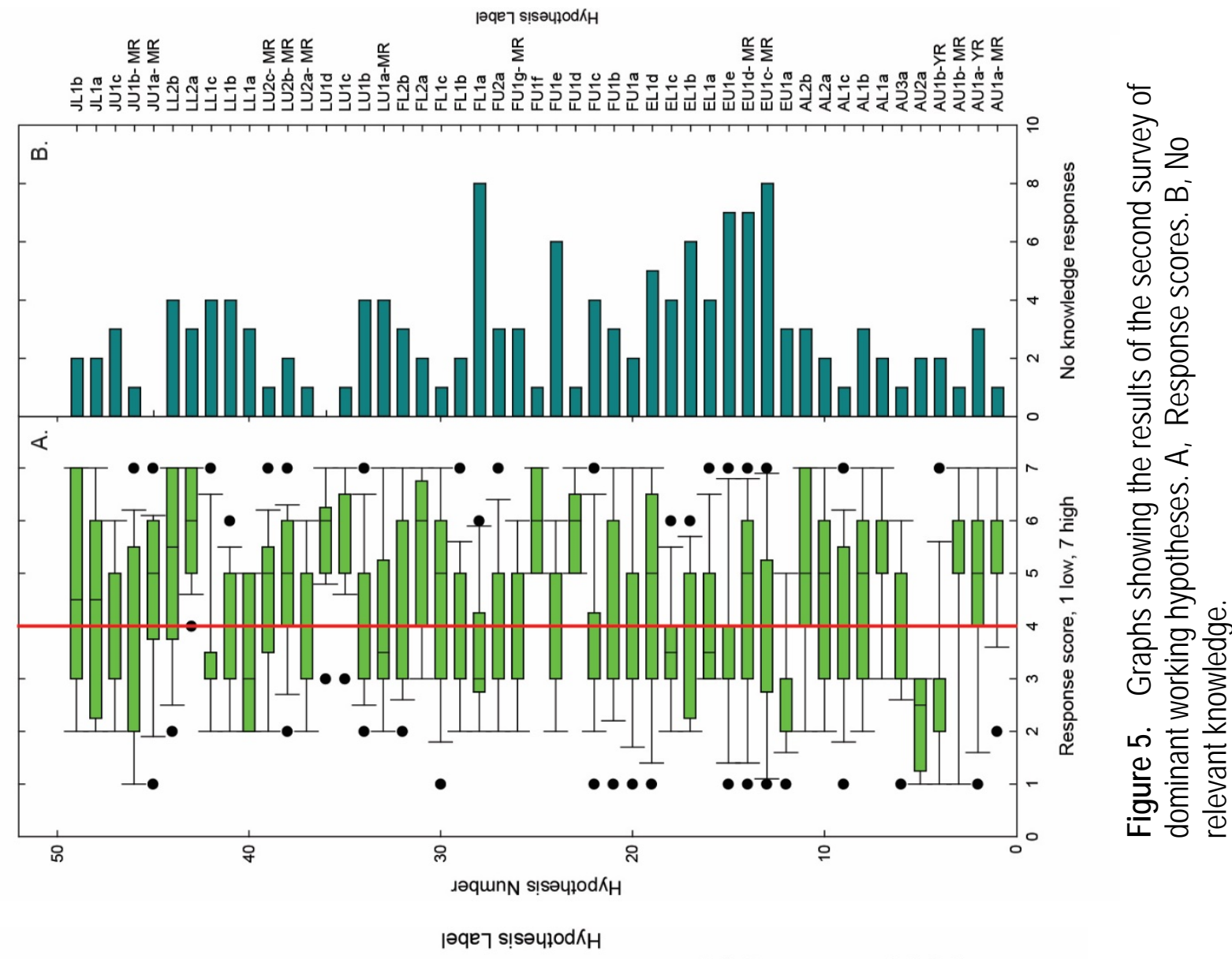

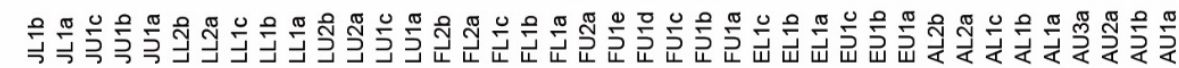

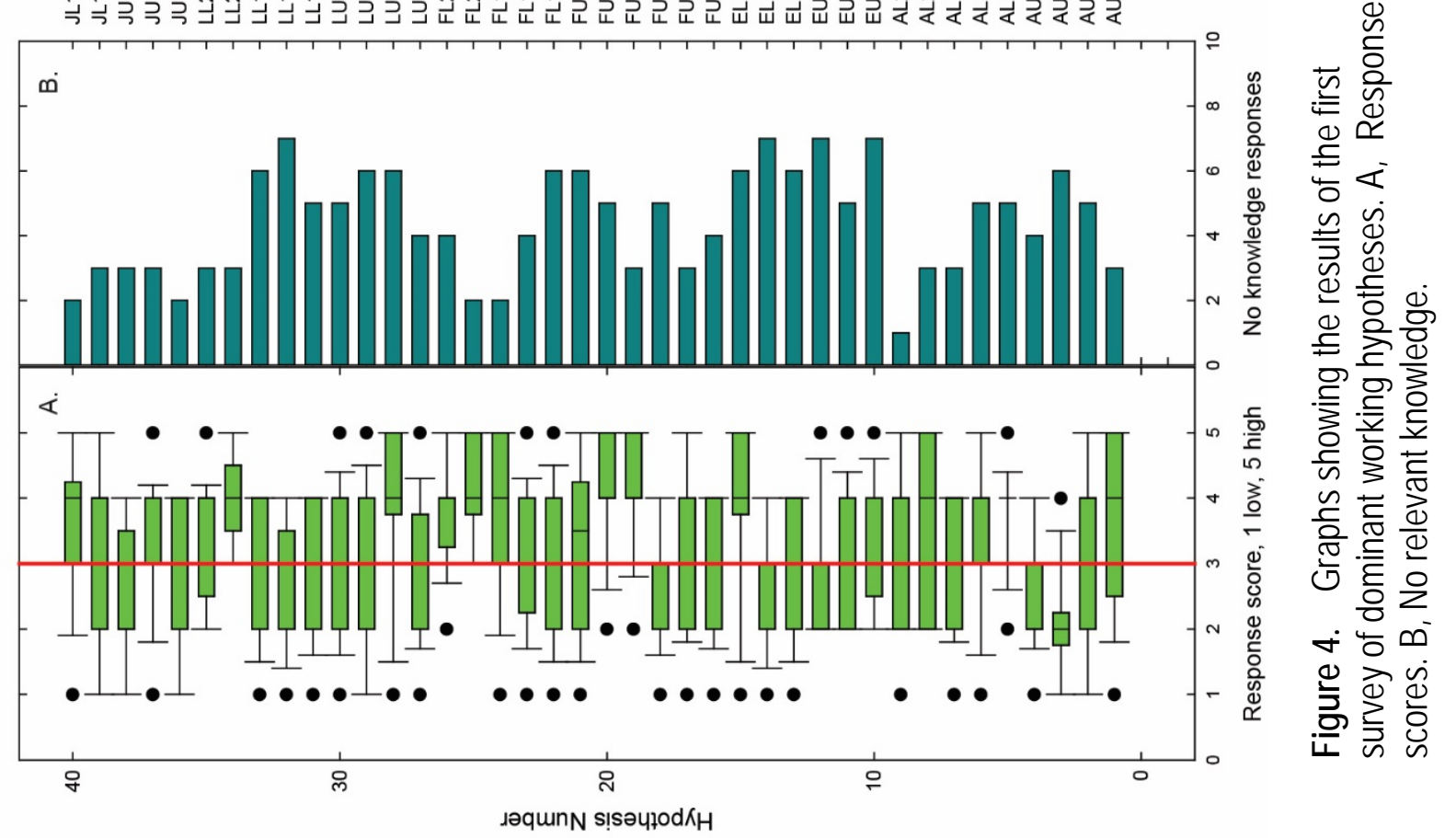


Table 3. Candidate dominant working hypotheses before second round of expert survey

[Hypotheses shaded in gray were those selected as working dominant hypotheses. Key for labels: A, Adult; E, Embryo; F, Free embryo; L, Larvae (exogenously feeding); J, Juvenile; YR, Yellowstone River; MR, Upper Missouri River]

\begin{tabular}{|c|c|c|c|}
\hline Number & & Label & Hypothesis \\
\hline & \multirow{7}{*}{ 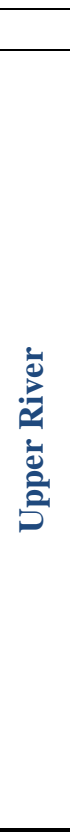 } & & Prespawn and spawning adults \\
\hline 1 & & $\begin{array}{l}\text { AU1a } \\
- \text { MR }\end{array}$ & $\begin{array}{l}\text { ADULTS, UPPER RIVER, MISSOURI - Barriers to upstream migration prevent } \\
\text { access to functional spawning sites with supportive hydraulics and substrate. }\end{array}$ \\
\hline 2 & & $\begin{array}{l}\text { AU1a } \\
\text { - YR }\end{array}$ & $\begin{array}{l}\text { ADULTS, UPPER RIVER, YELLOWSTONE - Barriers to upstream migration } \\
\text { prevent access to functional spawning sites with supportive hydraulics and } \\
\text { substrate. }\end{array}$ \\
\hline 3 & & $\begin{array}{l}\text { AU1b } \\
- \text { MR }\end{array}$ & $\begin{array}{l}\text { ADULTS, UPPER RIVER, MISSOURI - Hydrology-related events (for example, } \\
\text { pulsed flows, water temperature variation, during the adult reproductive period) } \\
\text { are inadequate to cue aggregation of reproductive adults, decreasing probability } \\
\text { of mates to find one another. }\end{array}$ \\
\hline 4 & & $\begin{array}{l}\text { AU1b } \\
- \text { YR }\end{array}$ & $\begin{array}{l}\text { ADULTS, UPPER RIVER, YELLOWSTONE - Hydrology-related events (for } \\
\text { example, pulsed flows, water temperature variation, during the adult } \\
\text { reproductive period) are inadequate to cue aggregation of reproductive adults, } \\
\text { decreasing probability of mates to find one another. }\end{array}$ \\
\hline 5 & & AU2a & $\begin{array}{l}\text { ADULTS, UPPER RIVER - Take of prespawn adults through poaching or other } \\
\text { mechanisms is a significant source of direct mortality. }\end{array}$ \\
\hline 6 & & AU3a & $\begin{array}{l}\text { ADULTS, UPPER RIVER - Number of conspecifics creates density-dependent } \\
\text { competition for available prey, leading to reduced pallid growth, condition, and } \\
\text { fecundity. }\end{array}$ \\
\hline 7 & \multirow{6}{*}{ 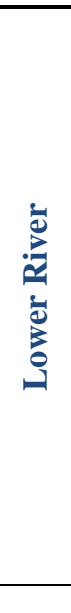 } & AL1a & $\begin{array}{l}\text { ADULTS, LOWER RIVER - Decreased separation of reproductive shovelnose and } \\
\text { pallid sturgeon in space and time has resulted in increased hybridization, } \\
\text { decreased genetic distinctness. }\end{array}$ \\
\hline 8 & & AL1b & $\begin{array}{l}\text { ADULTS, LOWER RIVER - Too much attractive spawning substrate decreases } \\
\text { probability of pallid mates finding one another. }\end{array}$ \\
\hline 9 & & AL1c & $\begin{array}{l}\text { ADULTS, LOWER RIVER - Hydrology-related events (for example, pulsed flows, } \\
\text { water temperature variation, during the adult reproductive period) are inadequate } \\
\text { to cue aggregation of reproductive adults, decreasing probability of mates to find } \\
\text { one another. }\end{array}$ \\
\hline 10 & & AL2a & $\begin{array}{l}\text { ADULTS, LOWER RIVER - Decreased food availability has led to decreased } \\
\text { growth, condition, and fecundity. }\end{array}$ \\
\hline \multirow[t]{2}{*}{11} & & AL2b & $\begin{array}{l}\text { ADULTS, LOWER RIVER - High water velocity and insufficient habitat } \\
\text { complexity (for example, lack of refugia to conserve energy) have led to } \\
\text { decreased growth, condition, and fecundity. }\end{array}$ \\
\hline & & & Gametes and Developing Embryos \\
\hline 12 & \multirow{4}{*}{ 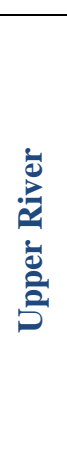 } & EU1a & $\begin{array}{l}\text { GAMETES, EMBRYOS, UPPER RIVER - Vertical transmission of contaminants } \\
\text { causes significant loss of viability in gametes or direct mortality in developing } \\
\text { embryos. }\end{array}$ \\
\hline 13 & & EU1c & $\begin{array}{l}\text { GAMETES, EMBRYOS, UPPER RIVER, MISSOURI - Probability of predation } \\
\text { prior to hatch is high due to hypolimnetic releases of cold water that prolong } \\
\text { embryo incubation time. }\end{array}$ \\
\hline 14 & & EU1d & $\begin{array}{l}\text { GAMETES, EMBRYOS, UPPER RIVER, MISSOURI - Predation rate on } \\
\text { embryos prior to hatch is high due to low turbidity (increased efficacy of sight- } \\
\text { feeding predators). }\end{array}$ \\
\hline 15 & & EU1e & $\begin{array}{l}\text { GAMETES, EMBRYOS, UPPER RIVER - Predation rate on embryos prior to } \\
\text { hatch has increased due to increased numbers of predators. }\end{array}$ \\
\hline
\end{tabular}


Table 3. Candidate working dominant hypotheses before second round of expert survey - Continued

\begin{tabular}{|c|c|c|c|}
\hline Number & & Label & Hypothesis \\
\hline & & & Gametes and Developing Embryos (Continued) \\
\hline 16 & \multirow{4}{*}{ 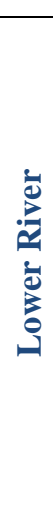 } & EL1a & $\begin{array}{l}\text { GAMETES, EMBRYOS, LOWER RIVER - Vertical transmission of contaminants } \\
\text { causes significant loss of viability in gametes or direct mortality in developing } \\
\text { embryos. }\end{array}$ \\
\hline 17 & & EL1b & $\begin{array}{l}\text { GAMETES, EMBRYOS, LOWER RIVER - Predation rate on embryos prior to } \\
\text { hatch has increased due to low turbidity (increased efficacy of sight-feeding } \\
\text { predators). }\end{array}$ \\
\hline 18 & & EL1c & $\begin{array}{l}\text { GAMETES, EMBRYOS, LOWER RIVER - Predation rate on embryos prior to } \\
\text { hatch has increased due to increased numbers of predators. }\end{array}$ \\
\hline 19 & & EL1d & $\begin{array}{l}\text { GAMETES, EMBRYOS, LOWER RIVER - Direct mortality of embryos by } \\
\text { detachment, entrainment, or sedimentation (by crushing or smothering) has } \\
\text { increased due to increased scour and sediment deposition at embryo incubation } \\
\text { locations. }\end{array}$ \\
\hline \multicolumn{4}{|r|}{ Free Embryos } \\
\hline 20 & \multirow{8}{*}{ 离 } & FU1a & $\begin{array}{l}\text { FREE EMBRYOS, UPPPER RIVER, MISSOURI - Probability of predation prior to } \\
\text { settling is high due to hypolimnetic releases of cold water that prolong free } \\
\text { embryo development. }\end{array}$ \\
\hline 21 & & FU1b & $\begin{array}{l}\text { FREE EMBRYOS, UPPPER RIVER, MISSOURI - Predation rate on free embryos } \\
\text { prior to settling is high due to low turbidity (increased efficacy of sight-feeding } \\
\text { predators). }\end{array}$ \\
\hline 22 & & FU1c & $\begin{array}{l}\text { FREE EMBRYOS, UPPPER RIVER - Predation rate on free embryos prior to } \\
\text { settling has increased due to increased numbers of predators. }\end{array}$ \\
\hline 23 & & FU1d & $\begin{array}{l}\text { FREE EMBRYOS, UPPPER RIVER - Free embryos transported into headwaters of } \\
\text { reservoirs suffer direct mortality through lethal water-quality conditions, such as } \\
\text { anoxia. }\end{array}$ \\
\hline 24 & & FU1e & $\begin{array}{l}\text { FREE EMBRYOS, UPPPER RIVER -Free embryos transported into headwaters of } \\
\text { reservoirs starve because habitat conditions are unsuitable for first feeding (areas } \\
\text { without sufficient prey base). }\end{array}$ \\
\hline 25 & & FU1f & $\begin{array}{l}\text { FREE EMBRYOS, UPPER RIVER - Free embryos are transported into non- } \\
\text { supporting habitats because barriers limit upstream adult migration or reservoirs } \\
\text { limit downstream dispersal. }\end{array}$ \\
\hline 26 & & FU1g & $\begin{array}{l}\text { FREE EMBRYOS, UPPER RIVER, MISSOURI - Free embryos are transported } \\
\text { into non-supporting habitats because of increased velocities associated with flow } \\
\text { management. }\end{array}$ \\
\hline 27 & & FU2a & $\begin{array}{l}\text { FREE EMBRYOS, UPPER RIVER. MISSOURI - Changes in flow regime, water } \\
\text { quality, and/or local habitat in settling areas have decreased the prey base for } \\
\text { first-feeding, significantly decreasing growth, condition, and survival. }\end{array}$ \\
\hline 28 & \multirow{4}{*}{ 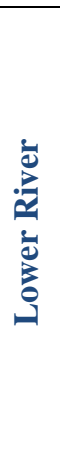 } & FL1a & $\begin{array}{l}\text { FREE EMBRYOS, LOWER RIVER - Direct mortality has increased due to } \\
\text { predation because substrate does not provide sufficient refugia. }\end{array}$ \\
\hline 29 & & FL1b & $\begin{array}{l}\text { FREE EMBRYOS, LOWER RIVER - Predation rate on free embryos prior to } \\
\text { settlement has increased due to low turbidity (increased efficacy of sight-feeding } \\
\text { predators). }\end{array}$ \\
\hline 30 & & FL1c & $\begin{array}{l}\text { FREE EMBRYOS, LOWER RIVER - Direct mortality has increased due to } \\
\text { starvation, inability to transition to first feeding because hydraulic conditions do } \\
\text { not allow a free embryo to settle into areas with prey. }\end{array}$ \\
\hline 31 & & FL2a & $\begin{array}{l}\text { FREE EMBRYOS, LOWER RIVER - Growth, condition, and survival have } \\
\text { decreased because increased water velocity and lack of habitat complexity have } \\
\text { led to unsuitable habitat conditions for first feeding. }\end{array}$ \\
\hline
\end{tabular}


Table 3. Candidate working dominant hypotheses before second round of expert survey - Continued

\begin{tabular}{|c|c|c|c|}
\hline Number & & Label & Hypothesis \\
\hline & & & Free Embryos (Continued) \\
\hline 32 & 党离 & FL2b & $\begin{array}{l}\text { FREE EMBRYOS, LOWER RIVER - Growth, condition, and survival have } \\
\text { decreased because flow regime, water quality, and lack of habitat complexity at } \\
\text { settling locations have resulted in lack of suitable prey resources for first feeding. }\end{array}$ \\
\hline & & & Exogenously Feeding Larvae \\
\hline 33 & \multirow{7}{*}{ 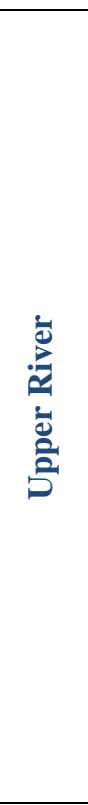 } & LU1a & $\begin{array}{l}\text { EXO LARVAE, UPPER RIVER, MISSOURI - Predation rate on larvae has } \\
\text { increased due to low turbidity (increased efficacy of sight-feeding predators). }\end{array}$ \\
\hline 34 & & LU1b & $\begin{array}{l}\text { EXO LARVAE, UPPER RIVER - Predation rate on larvae has increased due to } \\
\text { increased numbers of introduced or invasive predators. }\end{array}$ \\
\hline 35 & & LU1c & $\begin{array}{l}\text { EXO LARVAE, UPPER RIVER - Exo larvae dispersing into headwaters of } \\
\text { reservoirs suffer direct mortality through lethal water-quality conditions, such as } \\
\text { anoxia. }\end{array}$ \\
\hline 36 & & LU1d & $\begin{array}{l}\text { EXO LARVAE, UPPER RIVER - Exo larvae disperse into non-supporting habitats } \\
\text { because barriers limit upstream adult migration or reservoirs limit downstream } \\
\text { dispersal. }\end{array}$ \\
\hline 37 & & LU2a & $\begin{array}{l}\text { EXO LARVAE, UPPER RIVER, MISSOURI - Exo larvae disperse into non- } \\
\text { supporting habitats because of increased velocities associated with flow } \\
\text { management. }\end{array}$ \\
\hline 38 & & LU2b & $\begin{array}{l}\text { EXO LARVAE, UPPER RIVER, MISSOURI - Growth, condition, and survival in } \\
\text { the Missouri River have decreased due to seasonal reservoir water releases that } \\
\text { alter water velocity and habitat. }\end{array}$ \\
\hline 39 & & LU2c & $\begin{array}{l}\text { EXO LARVAE, UPPER RIVER. MISSOURI - Growth, condition, and survival } \\
\text { have decreased due to changes in flow regime, water quality, and/or local habitat } \\
\text { that have decreased the prey base. }\end{array}$ \\
\hline 40 & \multirow{5}{*}{ 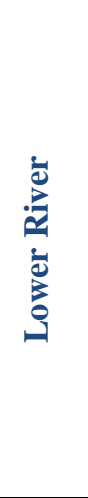 } & LL1a & $\begin{array}{l}\text { EXO LARVAE, LOWER RIVER - Predation rate on larvae is high due to low } \\
\text { turbidity (increased efficacy of sight-feeding predators). }\end{array}$ \\
\hline 41 & & LL1b & $\begin{array}{l}\text { EXO LARVAE, LOWER RIVER - Predation rate on larvae has increased due to } \\
\text { increased numbers of introduced or invasive predators. }\end{array}$ \\
\hline 42 & & LL1c & $\begin{array}{l}\text { EXO LARVAE, LOWER RIVER - Predation rate on larvae has increased due to } \\
\text { increased quality of physical habitat for predators. }\end{array}$ \\
\hline 43 & & LL2a & $\begin{array}{l}\text { EXO LARVAE, LOWER RIVER - Growth, condition, and survival have decreased } \\
\text { due to altered flow regime and channelization that increase water velocity and } \\
\text { decrease supportive channel complexity. }\end{array}$ \\
\hline 44 & & LL2b & $\begin{array}{l}\text { EXO LARVAE, LOWER RIVER - Growth, condition, and survival have decreased } \\
\text { due to altered flow regime and channelization that decreases river productivity } \\
\text { (prey resources). }\end{array}$ \\
\hline \multicolumn{4}{|r|}{ Juveniles } \\
\hline 45 & \multirow{3}{*}{ 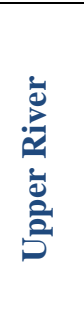 } & JU1a & $\begin{array}{l}\text { JUVENILES, UPPER RIVER, MISSOURI - Growth, condition, and survival have } \\
\text { decreased due to altered flow and temperature regimes that change bioenergetic } \\
\text { dynamics. }\end{array}$ \\
\hline 46 & & JU1b & $\begin{array}{l}\text { JUVENILES, UPPER RIVER, MISSOURI - Growth, condition, and survival have } \\
\text { decreased due to altered flow and temperature regimes that decreases river } \\
\text { productivity (prey resources). }\end{array}$ \\
\hline 47 & & JU1c & $\begin{array}{l}\text { JUVENILES, UPPER RIVER, MISSOURI - Growth, condition, and survival have } \\
\text { decreased due to increased conspecific competition. }\end{array}$ \\
\hline
\end{tabular}


Table 3. Candidate working dominant hypotheses before second round of expert survey - Continued

\begin{tabular}{|c|c|c|c|}
\hline Number & & Label & Hypothesis \\
\hline \multicolumn{4}{|r|}{ Juveniles (Continued) } \\
\hline 48 & $\sum_{\square}^{\beth}$ & JL1a & $\begin{array}{l}\text { JUVENILES, LOWER RIVER - Growth, condition, and survival have } \\
\text { decreased due to moderated discharge variation that reduces river } \\
\text { productivity (prey resources). }\end{array}$ \\
\hline 49 & בై & JL1b & $\begin{array}{l}\text { JUVENILES, LOWER RIVER. Growth, condition, and survival have } \\
\text { decreased due to insufficient habitat (channel complexity) that reduces } \\
\text { river productivity (prey resources). }\end{array}$ \\
\hline
\end{tabular}

the Missouri River and will be addressed in the Adaptive Management Plan (A. Quinn, U.S. Army Corps of Engineers, written commun., 2015).

All three rounds of surveys for dominant and management hypotheses included the opportunity for experts to select “Don't know, no relevant knowledge.” The number of responses in this category provides useful context for the hypothesis scores, indicating a level of uncertainty that may inform how hypotheses are addressed in the future. Hypotheses with high numbers of unknown responses, for example, may be candidates for resurrection from the reserve, for increased effort to decrease uncertainties during development of quantitative models, or for increased effort in design of research and monitoring. Management hypotheses with more than one-third of the experts selecting “Don't know, no relevant knowledge" include:

- Reduction of main-stem Missouri River flows from Fort Peck Dam during the spawning season will increase downstream turbidity by increasing proportional contribution from the turbid Milk River, thereby decreasing predation of embryos, free embryos, and exogenously feeding larvae.

- Removal of anoxic, flocculant sediment in the headwaters of Lake Sakakawea will decrease mortality of free embryos and exogenously feeding larvae due to lethal water quality.

- Increasing dissolved oxygen in headwaters using air diffusers or similar methods will increase survival of free embryos and exogenously feeding larvae.

- Naturalization of flow regime on the Platte River (Nebraska), will allow migration, spawning, and recruitment to the Missouri River population.

- Removal of migration barriers on the Kansas River will allow migration, spawning, and recruitment to the Missouri River population.

- Removal of migration barriers in the Osage River will allow migration, spawning, and recruitment to the Missouri River population.

- Channel reconfiguration in the Middle Mississippi River will increase retention, growth, survival, and recruitment of pallid sturgeon to the Missouri River population.

Five of these seven hypotheses address abiotic conditions outside of the main-stem Missouri River and the high rate of uncertainty may reflect the fact that the attention of pallid-sturgeon scientists has been focused on main-stem processes and has only lately moved toward the role of tributaries (U.S. Fish and Wildlife Service, 2014). Most of these highly uncertain hypotheses have both abiotic and biotic components, and focused effort on one or the other may provide enough information to reject or continue pursuit of a hypothesis. 
Table 4. Candidate working management hypotheses before third survey

\begin{tabular}{|c|c|c|}
\hline Number & What & Management Hypothesis \\
\hline & & Upper Missouri River \\
\hline 1 & \multirow{4}{*}{$\begin{array}{l}\text { Remove Fort } \\
\text { Peck Dam }\end{array}$} & $\begin{array}{l}\text { Removing Fort Peck Dam will allow reproductive pallid sturgeon to access upstream } \\
\text { functional spawning sites, increasing spawning success. }\end{array}$ \\
\hline 2 & & $\begin{array}{l}\text { Removing Fort Peck Dam will result in increased effective drift distance for } \\
\text { dispersing free embryos, decreasing downstream mortality. }\end{array}$ \\
\hline 3 & & $\begin{array}{l}\text { Removing Fort Peck Dam will naturalize the flow regime, resulting in increased } \\
\text { productivity, increased flow cues, and increased use of complex overbank } \\
\text { habitats. }\end{array}$ \\
\hline 4 & & $\begin{array}{l}\text { Removing Fort Peck Dam will increase and naturalize turbidity levels, resulting in } \\
\text { decreased predation on embryos, free embryos, and exo larvae. }\end{array}$ \\
\hline 5 & \multirow{7}{*}{$\begin{array}{l}\text { Alter Flow } \\
\text { Regime at } \\
\text { Fort Peck }\end{array}$} & $\begin{array}{l}\text { Naturalized flow releases at Fort Peck will result in increased productivity through } \\
\text { increased hydrologic connections with low-lying land and flood plains in the } \\
\text { spring, and decreased velocities and bioenergetic demands on exo larvae and } \\
\text { juveniles during low flows in summer and fall. }\end{array}$ \\
\hline 6 & & $\begin{array}{l}\text { Naturalized flow releases at Fort Peck will result in increased reproductive success } \\
\text { through increased aggregation and spawning success of adults. }\end{array}$ \\
\hline 7 & & $\begin{array}{l}\text { Naturalized flow releases at Fort Peck will result in increased hydrologic connection } \\
\text { with low-lying land, increased growth rates, shorter drift distance, and increased } \\
\text { survival of free embryos. }\end{array}$ \\
\hline 8 & & $\begin{array}{l}\text { Reduction of main-stem Missouri River flows at Fort Peck Dam during the } \\
\text { spawning season will increase downstream turbidity by increasing proportional } \\
\text { contribution from the turbid Milk River, thereby decreasing predation of embryos, } \\
\text { free embryos, and exo larvae. }\end{array}$ \\
\hline 9 & & $\begin{array}{l}\text { Reduction of main-stem Missouri River flows from Fort Peck Dam during free } \\
\text { embryo dispersal will decrease main-stem velocities and drift distance thereby } \\
\text { decreasing downstream mortality of free embryos and exo larvae. }\end{array}$ \\
\hline 10 & & $\begin{array}{l}\text { Provide spring pulsed flow releases from Fort Peck to draw reproductive adults up } \\
\text { Missouri River where potential dispersal distance (greater than Yellowstone) will } \\
\text { decrease downstream mortality of free embryos and exo larvae. }\end{array}$ \\
\hline 11 & & $\begin{array}{l}\text { In case where fish passage has been enhanced on Yellowstone, operate Fort Peck } \\
\text { releases to NOT draw reproductive adults up the Missouri. }\end{array}$ \\
\hline 12 & \multirow{3}{*}{$\begin{array}{l}\text { Install } \\
\quad \text { temperature } \\
\text { control, } \\
\text { multilevel- } \\
\text { release device } \\
\text { at Fort Peck }\end{array}$} & $\begin{array}{l}\text { Warmer flow releases at Fort Peck will increase system productivity and food } \\
\text { resources, increased growth and condition of exo larvae and juveniles. }\end{array}$ \\
\hline 13 & & $\begin{array}{l}\text { Warmer flow releases at Fort Peck will increase growth rates, shorten drift distance, } \\
\text { and increase survival of free embryos. }\end{array}$ \\
\hline 14 & & $\begin{array}{l}\text { Warmer flow releases at Fort Peck will result in increased growth rates of } \\
\text { exogenously feeding larvae, increase probability of surviving the first winter. }\end{array}$ \\
\hline 15 & $\begin{array}{l}\text { Sediment bypass } \\
\text { at Fort Peck } \\
\text { or other } \\
\text { sediment } \\
\text { augmentation. }\end{array}$ & $\begin{array}{l}\text { Installing sediment bypass at Fort Peck will increase and naturalize turbidity levels, } \\
\text { resulting in decreased predation on embryos, free embryos, and exo larvae. }\end{array}$ \\
\hline
\end{tabular}


Table 4. Candidate working management hypotheses before third survey - Continued

\begin{tabular}{|c|c|c|}
\hline Number & What & Management Hypothesis \\
\hline \multicolumn{3}{|r|}{ Yellowstone River } \\
\hline 16 & $\begin{array}{l}\text { Construct fish } \\
\text { passage at }\end{array}$ & $\begin{array}{l}\text { Fish passage on the Yellowstone River will allow access to additional functional } \\
\text { spawning sites, increasing spawning success. }\end{array}$ \\
\hline 17 & $\begin{array}{l}\text { Intake on } \\
\text { Yellowstone } \\
\text { River }\end{array}$ & $\begin{array}{l}\text { Fish passage on the Yellowstone River will result in increased effective drift } \\
\text { distance, decreasing downstream mortality of free embryos and exo larvae. }\end{array}$ \\
\hline 18 & $\begin{array}{l}\text { Removal of } \\
\text { Intake on }\end{array}$ & $\begin{array}{l}\text { Fish passage on the Yellowstone River will allow access to additional functional } \\
\text { spawning sites, increasing spawning success. }\end{array}$ \\
\hline 19 & $\begin{array}{l}\text { Yellowstone } \\
\text { River }\end{array}$ & $\begin{array}{l}\text { Fish passage on the Yellowstone will result in increased effective drift distance, } \\
\text { decreasing downstream mortality of free embryos and exo larvae. }\end{array}$ \\
\hline 20 & $\begin{array}{l}\text { Construct fish } \\
\text { passage at } \\
\text { Intake and } \\
\text { Cartersville }\end{array}$ & $\begin{array}{l}\text { Fish passage on the Yellowstone River will allow access to additional functional } \\
\text { spawning sites, increasing spawning success. }\end{array}$ \\
\hline 21 & $\begin{array}{l}\text { Dams on } \\
\text { Yellowstone } \\
\text { River }\end{array}$ & $\begin{array}{l}\text { Fish passage on the Yellowstone River will result in increased effective drift } \\
\text { distance, decreasing downstream mortality of free embryos and exo larvae. }\end{array}$ \\
\hline 22 & $\begin{array}{l}\text { Removal of } \\
\text { Intake and } \\
\text { Cartersville }\end{array}$ & $\begin{array}{l}\text { Fish passage on the Yellowstone River will allow access to additional functional } \\
\text { spawning sites, increasing spawning success. }\end{array}$ \\
\hline 23 & $\begin{array}{l}\text { Dams on } \\
\text { Yellowstone } \\
\text { River } \\
\end{array}$ & $\begin{array}{l}\text { Fish passage on the Yellowstone River will result in increased effective drift } \\
\text { distance, decreasing downstream mortality of free embryos and exo larvae. }\end{array}$ \\
\hline \multicolumn{3}{|r|}{ Yellowstone and Missouri Rivers } \\
\hline 24 & & $\begin{array}{l}\text { Reconfiguration of channel substrate in spawning patches will increase interstitial } \\
\text { space, retention, and survival of free embryos. }\end{array}$ \\
\hline 25 & $\begin{array}{l}\text { Channel } \\
\text { reconfiguration }\end{array}$ & $\begin{array}{l}\text { Reconfiguration of channels in both rivers will increase complexity and retention of } \\
\text { free embryos, decreasing effective drift distance, and thereby decreasing } \\
\text { downstream mortality. Reconfiguration will also increase productivity and food } \\
\text { resources, decreasing bioenergetic demand. }\end{array}$ \\
\hline 26 & Propagation & $\begin{array}{l}\text { Population augmentation will increase density of reproductive adult fish, resulting in } \\
\text { sufficient numbers of gametes and embryos to support natural recruitment. }\end{array}$ \\
\hline \multicolumn{3}{|r|}{ Lake Sakakawea } \\
\hline 27 & $\begin{array}{l}\text { Operate Garrison } \\
\text { Dam to draw } \\
\text { down Lake } \\
\text { Sakakawea }\end{array}$ & $\begin{array}{l}\text { Drawdown of Lake Sakakawea will increase effective drift distance, decreasing } \\
\text { downstream mortality of free embryos and exo larvae. }\end{array}$ \\
\hline 29 & $\begin{array}{l}\text { Improve } \\
\text { headwaters } \\
\text { water quality }\end{array}$ & $\begin{array}{l}\text { Removal of anoxic, flocculant sediment at headwaters of Lake Sakakawea will } \\
\text { decrease mortality of free embryos and exo larvae due to lethal water quality. } \\
\text { Increasing dissolved oxygen in headwaters using air diffusers or similar methods } \\
\text { will increase survival of free embryos and exo larvae. }\end{array}$ \\
\hline
\end{tabular}


Table 4. Candidate working management hypotheses before third survey - Continued

\begin{tabular}{|c|c|c|}
\hline Number & What & Management Hypothesis \\
\hline & & Lower Missouri River \\
\hline 30 & \multirow{6}{*}{$\begin{array}{l}\text { Alter flow regime } \\
\text { at Gavins Point }\end{array}$} & $\begin{array}{l}\text { Naturalization of the flow regime at Fort Peck will improve flow cues in spring } \\
\text { for aggregation and spawning of reproductive adults. }\end{array}$ \\
\hline 31 & & $\begin{array}{l}\text { Naturalization of the flow regime at Fort Peck will improve connectivity with } \\
\text { marginal habitats and low-lying lands, increase primary and secondary } \\
\text { production, and increase growth and condition of exogenously feeding larvae } \\
\text { and juveniles. }\end{array}$ \\
\hline 32 & & $\begin{array}{l}\text { Naturalization of the flow regime at Fort Peck will decrease velocities and } \\
\text { bioenergetic demands, resulting in increased growth and condition for exo } \\
\text { larvae and juveniles. }\end{array}$ \\
\hline 33 & & $\begin{array}{l}\text { Alteration of the flow regime at Fort Peck will prepare substrate in spawning } \\
\text { patches, resulting in increased success in spawning and incubation. }\end{array}$ \\
\hline 34 & & $\begin{array}{l}\text { Alteration of the flow regime at Fort Peck will decrease scour during incubation, } \\
\text { resulting in increased embryo survival. }\end{array}$ \\
\hline 35 & & $\begin{array}{l}\text { Alteration of the flow regime at Fort Peck can be optimized to decrease main-stem } \\
\text { velocities, decrease effective drift distance, and avoid downstream mortality. }\end{array}$ \\
\hline 36 & \multirow{3}{*}{$\begin{array}{l}\text { Temperature } \\
\text { management at } \\
\text { Fort Randall and } \\
\text { Gavins Point }\end{array}$} & $\begin{array}{l}\text { Operation of a temperature management system at Fort Randall and(or) Gavins } \\
\text { Point will increase water temperature downstream of Gavins Point, providing } \\
\text { spawning cues for reproductive adults. }\end{array}$ \\
\hline & & Operation of a temperature management system at Fort Randall and(or) Gavins \\
\hline 37 & & $\begin{array}{l}\text { Point will increase water temperature downstream of Gavins Point, increasing } \\
\text { growth rates for free embryos, exo larvae, and juveniles. }\end{array}$ \\
\hline 38 & \multirow{5}{*}{$\begin{array}{l}\text { Channel } \\
\text { reconfiguration }\end{array}$} & $\begin{array}{l}\text { Re-engineering of channel morphology in selected reaches will create optimal } \\
\text { spawning conditions — substrate, hydraulics, and geometry—to increase } \\
\text { probability of successful spawning, fertilization, embryo incubation, and free- } \\
\text { embryo retention, and to separate reproductive pallid sturgeon and shovelnose } \\
\text { sturgeon, thereby decreasing probability of hybridization. }\end{array}$ \\
\hline 39 & & $\begin{array}{l}\text { Re-engineering of channel morphology in selected reaches will increase channel } \\
\text { complexity and bioenergetic conditions to increase prey density (invertebrates } \\
\text { and native prey fish) for exo larvae and juveniles. }\end{array}$ \\
\hline 40 & & $\begin{array}{l}\text { Re-engineering of channel morphology will increase channel complexity and } \\
\text { maximize bioenergetic conditions for resting, migration, and foraging of adults. }\end{array}$ \\
\hline 41 & & $\begin{array}{l}\text { Re-engineering of channel morphology in selected reaches will increase channel } \\
\text { complexity and serve specifically to intercept and retain drifting free embryos in } \\
\text { areas with sufficient prey for first feeding and for growth through juvenile } \\
\text { stages. }\end{array}$ \\
\hline 42 & & $\begin{array}{l}\text { Re-engineering of channel morphology in selected reaches will increase channel } \\
\text { complexity to increase primary and secondary productivity, and prey-fish } \\
\text { production thereby increasing growth and condition of exo larvae through } \\
\text { juvenile stages. }\end{array}$ \\
\hline 43 & \multirow{2}{*}{$\begin{array}{l}\text { Water quality } \\
\text { management }\end{array}$} & $\begin{array}{l}\text { Regulation of agricultural runoff and municipal waste discharge will decrease } \\
\text { exposure to endocrine-disrupting chemicals, thereby decreasing incidence of } \\
\text { intersex and increasing reproductive success of adults. }\end{array}$ \\
\hline 44 & & $\begin{array}{l}\text { Regulation of agricultural and urban runoff will decrease biological oxygen } \\
\text { demand, increase dissolved oxygen, and thereby increase growth, condition and } \\
\text { survival of free embryos and exo larvae. }\end{array}$ \\
\hline 45 & \multirow{2}{*}{$\begin{array}{l}\text { Sediment bypass } \\
\text { at Gavins Point }\end{array}$} & $\begin{array}{l}\text { Operation of a sediment bypass system at Gavins Point Dam will increase } \\
\text { turbidity and decrease mortality of free embryos and exo larvae from predation. }\end{array}$ \\
\hline 46 & & $\begin{array}{l}\text { Control of native and non-native predators through harvest or other mechanisms } \\
\text { will increase survival of embryos, free embryos, and exo larvae. }\end{array}$ \\
\hline
\end{tabular}


Table 4. Candidate working management hypotheses before third survey - Continued

\begin{tabular}{|c|c|c|}
\hline Number & What & Management Hypothesis \\
\hline & & Lower Missouri River (Continued) \\
\hline 47 & \multirow{2}{*}{$\begin{array}{l}\text { Competition } \\
\text { control }\end{array}$} & $\begin{array}{l}\text { Increasing/allowing commercial harvest of shovelnose sturgeon will decrease } \\
\text { probabilities of hybridization between shovelnose and pallid sturgeon. }\end{array}$ \\
\hline 48 & & $\begin{array}{l}\text { Control of conspecific species through harvest or other mechanisms will decrease } \\
\text { competition for food and space for exo larvae and juveniles. }\end{array}$ \\
\hline 49 & $\begin{array}{l}\text { Flow regime Platte } \\
\text { River }\end{array}$ & $\begin{array}{l}\text { Naturalization of flow regime on the Platte River (Nebraska), will allow } \\
\text { migration, spawning, and recruitment to the Missouri River population. }\end{array}$ \\
\hline 50 & \multirow{2}{*}{ Migration barriers } & $\begin{array}{l}\text { Removal of migration barriers on the Kansas River will allow migration, } \\
\text { spawning, and recruitment to the Missouri River population. }\end{array}$ \\
\hline 51 & & $\begin{array}{l}\text { Removal of migration barrier in the Osage River will allow migration, spawning, } \\
\text { and recruitment to the Missouri River population. }\end{array}$ \\
\hline 52 & $\begin{array}{l}\text { Channel } \\
\text { reconfiguration, } \\
\text { Mississippi } \\
\text { River } \\
\end{array}$ & $\begin{array}{l}\text { Channel reconfiguration in the Middle Mississippi River will increase retention, } \\
\text { growth, survival, and recruitment of pallid sturgeon to the Missouri River } \\
\text { population. }\end{array}$ \\
\hline 53 & Propagation & $\begin{array}{l}\text { Increasing numbers of pallid sturgeon propagated will decrease probability of } \\
\text { hybridization with shovelnose sturgeon. }\end{array}$ \\
\hline
\end{tabular}

For example, the hypothesis regarding Platte River flow regime can be considered in two parts: a) flow management on the Platte River may have an appreciable effect on flow regime in the Lower Platte River, given available water and geographic locations of Platte River reservoirs; and, b) given a more favorable flow regime, pallid sturgeon might use the Platte River for successful reproduction. The former question can be addressed with existing data and understanding (and has been investigated through the Platte River Recovery Implementation Program, (Parham, 2007; Smith, 2011)). The latter is a more difficult question. Ancillary information gathered during investigations of reproductive ecology of pallid sturgeon in the main-stem Missouri River has documented spawning of pallid sturgeon in the Platte River (DeLonay and others, 2012; DeLonay and others, 2016) but a more definitive answer about whether pallid sturgeon use of the Platte River would result in increases in population may require specifically focused future research.

\section{Implications of the Hypothesis Filtering Process}

The need to filter through global, to dominant working, to working management, to initially modeled hypotheses is a simple practicality. Among the thousands of possible linkages from management to pallid sturgeon population dynamics, a reasonable number of hypotheses need to be selected to start the modeling process and to define the required scope and supporting hydrology and hydraulic models. The process we used to do this necessarily depended on expert opinion to a large extent. Experts from throughout the basin and of varying backgrounds were invited to participate to limit potential bias in perspective and expertise. This process was systematic and quantitative, and importantly, it was documented so those hypotheses that were not carried forward at each step were documented and can be resurrected at any time as needed. The Adaptive Management Plan, which is currently (2015) being created, will address the process needed to reanalyze these reserve hypotheses. 
Table 5. Working set of management hypotheses after expert elicitation

[Shaded hypotheses were considered by USACE to be outside their jurisdictions or authorities. Unshaded hypotheses are identified as the initially modeled set under EA Phase 1]

\begin{tabular}{|c|c|c|c|}
\hline What & $\begin{array}{l}\text { Original } \\
\text { Number }\end{array}$ & $\begin{array}{l}\text { Working } \\
\text { Set } \\
\text { Number }\end{array}$ & Management Hypothesis \\
\hline \multicolumn{4}{|c|}{ Upper Missouri River } \\
\hline \multirow{4}{*}{$\begin{array}{l}\text { Remove Fort } \\
\text { Peck Dam }\end{array}$} & 1 & 1 & $\begin{array}{l}\text { Removing Fort Peck Dam will allow reproductive pallid sturgeon to } \\
\text { access upstream functional spawning sites, increasing spawning } \\
\text { success. }\end{array}$ \\
\hline & 2 & 2 & $\begin{array}{l}\text { Removing Fort Peck Dam will result in increased effective drift } \\
\text { distance for dispersing free embryos, decreasing downstream } \\
\text { mortality of free embryos and exogenously feeding larvae. }\end{array}$ \\
\hline & 3 & 3 & $\begin{array}{l}\text { Removing Fort Peck Dam will naturalize the flow regime, resulting in } \\
\text { increased productivity for all life stages, increased flow cues for } \\
\text { spawning adults, and increased use of complex overbank habitats. }\end{array}$ \\
\hline & 4 & 4 & $\begin{array}{l}\text { Removing Fort Peck Dam will increase and naturalize turbidity levels, } \\
\text { resulting in decreased predation on embryos, free embryos, and } \\
\text { exogenously feeding larvae. }\end{array}$ \\
\hline \multirow{3}{*}{$\begin{array}{l}\text { Alter flow } \\
\text { regime at Fort } \\
\text { Peck }\end{array}$} & 5 & 5 & $\begin{array}{l}\text { Naturalized flow releases at Fort Peck will result in increased } \\
\text { productivity through increased hydrologic connections with low- } \\
\text { lying land and flood plains in the spring, and decreased velocities } \\
\text { and bioenergetic demands on exogenously feeding larvae and } \\
\text { juveniles during low flows in summer and fall. }\end{array}$ \\
\hline & 6 & 6 & $\begin{array}{l}\text { Naturalized flow releases at Fort Peck will result in increased } \\
\text { reproductive success through increased aggregation and spawning } \\
\text { success of adults. }\end{array}$ \\
\hline & 9 & 7 & $\begin{array}{l}\text { Reduction of main-stem Missouri River flows from Fort Peck Dam } \\
\text { during free embryo dispersal will decrease main-stem velocities and } \\
\text { drift distance thereby decreasing downstream mortality of free } \\
\text { embryos and exogenously feeding larvae. }\end{array}$ \\
\hline \multirow{2}{*}{$\begin{array}{l}\text { Temperature } \\
\text { control, } \\
\text { multilevel- } \\
\text { release device } \\
\text { at Fort Peck }\end{array}$} & 12 & 8 & $\begin{array}{l}\text { Warmer flow releases at Fort Peck will increase system productivity } \\
\text { and food resource availability, thereby increasing growth and } \\
\text { condition of exogenously feeding larvae and juveniles. }\end{array}$ \\
\hline & 13 & 9 & $\begin{array}{l}\text { Warmer flow releases from Fort Peck will increase growth rates, } \\
\text { shorten drift distance, and increase survival of free embryos. }\end{array}$ \\
\hline $\begin{array}{l}\text { Sediment bypass } \\
\text { at Fort Peck or } \\
\text { other sediment } \\
\text { augmentation. }\end{array}$ & 15 & 10 & $\begin{array}{l}\text { Installing sediment bypass at Fort Peck will increase and naturalize } \\
\text { turbidity levels, resulting in decreased predation on embryos, free } \\
\text { embryos, and exogenously feeding larvae. }\end{array}$ \\
\hline
\end{tabular}

Our process built on hundreds of person-years of experience in the EA team and supporting experts, previous integrative efforts (2014 recovery plan, (U.S. Fish and Wildlife Service, 2014), and on a steadily increasing foundation of pallid sturgeon science. Research, monitoring, and assessment of pallid sturgeon have increased markedly since about 2000, as indicated by the number of peer-reviewed scientific publications that emerge from a standard reference search (fig. 8). The surge generally coincides with the 2000 and 2003 "Biological Opinions" and the 2004 "Missouri River Master Manual," which together called for increasing emphasis on building the scientific foundation for managing the Missouri River to promote recovery of the pallid sturgeon (U.S. Fish and Wildlife Service, 2000b, 2003; Quist and others, 2004; U.S. Army Corps of Engineers, 2006). 
Table 5. Working set of management hypotheses after expert elicitation - Continued

\begin{tabular}{|c|c|c|c|}
\hline What & $\begin{array}{l}\text { Original } \\
\text { Number }\end{array}$ & $\begin{array}{l}\text { Working } \\
\text { Set } \\
\text { Number }\end{array}$ & Management Hypothesis \\
\hline \multicolumn{4}{|r|}{ Yellowstone River } \\
\hline $\begin{array}{l}\text { Construct fish } \\
\text { passage at Intake } \\
\text { on Yellowstone } \\
\text { River }\end{array}$ & 17 & 11 & $\begin{array}{l}\text { Fish passage at Intake Dam on the Yellowstone River will allow access } \\
\text { to additional functional spawning sites, increasing spawning success } \\
\text { and effective drift distance, and decreasing downstream mortality of } \\
\text { free embryos and exogenously feeding larvae. }\end{array}$ \\
\hline $\begin{array}{l}\text { Removal of Intake } \\
\text { on Yellowstone } \\
\text { River }\end{array}$ & 18 & 12 & $\begin{array}{l}\text { Fish passage at Intake Dam on the Yellowstone River will allow access } \\
\text { to additional functional spawning sites, increasing spawning success } \\
\text { and effective drift distance, and decreasing downstream mortality of } \\
\text { free embryos and exogenously feeding larvae. }\end{array}$ \\
\hline $\begin{array}{l}\text { Construct fish } \\
\text { passage at Intake } \\
\text { and Cartersville } \\
\text { Dams on } \\
\text { Yellowstone } \\
\text { River }\end{array}$ & 19 & 13 & $\begin{array}{l}\text { Fish passage at Intake and Cartersville Dams on the Yellowstone River } \\
\text { will allow access to additional functional spawning sites, increasing } \\
\text { spawning success and effective drift distance, and decreasing } \\
\text { downstream mortality of free embryos and exogenously feeding } \\
\text { larvae. }\end{array}$ \\
\hline $\begin{array}{l}\text { Removal of Intake } \\
\text { and Cartersville } \\
\text { Dams on } \\
\text { Yellowstone } \\
\text { River }\end{array}$ & 20 & 14 & $\begin{array}{l}\text { Fish passage at Intake and Cartersville Dams on the Yellowstone River } \\
\text { will allow access to additional functional spawning sites, increasing } \\
\text { spawning success and effective drift distance, and decreasing } \\
\text { downstream mortality of free embryos and exogenously feeding } \\
\text { larvae. }\end{array}$ \\
\hline \multirow[b]{2}{*}{$\begin{array}{l}\text { Upper Basin } \\
\text { propagation }\end{array}$} & 26 & 15 & $\begin{array}{l}\text { Stocking at optimal size classes will increase growth rates and survival } \\
\text { of exogenously feeding larvae and juveniles. }\end{array}$ \\
\hline & 27 & 16 & $\begin{array}{l}\text { Stocking with appropriate parentage and genetic diversity will result in } \\
\text { increased survival of embryos, free embryos, exogenously feeding } \\
\text { larvae, and juveniles. }\end{array}$ \\
\hline \multicolumn{4}{|r|}{ Lake Sakakawea } \\
\hline $\begin{array}{l}\text { Operate Garrison } \\
\text { Dam to draw } \\
\text { down Lake } \\
\text { Sakakawea }\end{array}$ & 28 & 17 & $\begin{array}{l}\text { Drawdown of Lake Sakakawea will increase effective drift distance, } \\
\text { decreasing downstream mortality of free embryos and exogenously } \\
\text { feeding larvae. }\end{array}$ \\
\hline \multicolumn{4}{|r|}{ Lower Missouri River } \\
\hline \multirow{4}{*}{$\begin{array}{r}\text { Alter flow regime } \\
\text { at Gavins Point }\end{array}$} & 31 & 18 & $\begin{array}{l}\text { Naturalization of the flow regime at Gavins Point will improve flow } \\
\text { cues in spring for aggregation and spawning of reproductive adults. }\end{array}$ \\
\hline & 32 & 19 & $\begin{array}{l}\text { Naturalization of the flow regime at Gavins Point will improve } \\
\text { connectivity with marginal habitats and low-lying lands, increase } \\
\text { primary and secondary production, and increase growth and condition } \\
\text { of exogenously feeding larvae and juveniles. }\end{array}$ \\
\hline & 33 & 20 & $\begin{array}{l}\text { Naturalization of the flow regime at Gavins Point will decrease } \\
\text { velocities and bioenergetic demands, resulting in increased growth } \\
\text { and condition for exogenously feeding larvae and juveniles. }\end{array}$ \\
\hline & 36 & 21 & $\begin{array}{l}\text { Alteration of the flow regime at Gavins Point can be optimized to } \\
\text { decrease main-stem velocities, decrease effective drift distance, and } \\
\text { minimize mortality. }\end{array}$ \\
\hline $\begin{array}{l}\text { Temperature } \\
\text { management at } \\
\text { Fort Randall and } \\
\text { Gavins Point }\end{array}$ & 37 & 22 & $\begin{array}{l}\text { Operation of a temperature management system at Fort Randall and(or) } \\
\text { Gavins Point will increase water temperature downstream of Gavins } \\
\text { Point, providing spawning cues for reproductive adults. }\end{array}$ \\
\hline
\end{tabular}


Table 5. Working set of management hypotheses after expert elicitation - Continued

\begin{tabular}{|c|c|c|c|}
\hline What & $\begin{array}{l}\text { Original } \\
\text { Number }\end{array}$ & $\begin{array}{l}\text { Working } \\
\text { Set } \\
\text { Number }\end{array}$ & Management Hypothesis \\
\hline \multicolumn{4}{|c|}{ Lower Missouri River (Continued) } \\
\hline \multirow{4}{*}{$\begin{array}{l}\text { Channel } \\
\text { reconfiguration }\end{array}$} & 39 & 23 & $\begin{array}{l}\text { Re-engineering of channel morphology in selected reaches will } \\
\text { create optimal spawning conditions -- substrate, hydraulics, and } \\
\text { geometry -- to increase probability of successful spawning, } \\
\text { fertilization, embryo incubation, and free-embryo retention. }\end{array}$ \\
\hline & 41 & 24 & $\begin{array}{l}\text { Re-engineering of channel morphology in selected reaches will } \\
\text { increase channel complexity and bioenergetic conditions to } \\
\text { increase prey density (invertebrates and native prey fish) for } \\
\text { exogenously feeding larvae and juveniles. }\end{array}$ \\
\hline & 42 & 25 & $\begin{array}{l}\text { Re-engineering of channel morphology will increase channel } \\
\text { complexity and minimize bioenergetic requirements for resting } \\
\text { and foraging of exogenously feeding larvae and juveniles. }\end{array}$ \\
\hline & 43 & 26 & $\begin{array}{l}\text { Re-engineering of channel morphology in selected reaches will } \\
\text { increase channel complexity and serve specifically to intercept } \\
\text { and retain drifting free embryos in areas with sufficient prey for } \\
\text { first feeding and for growth through juvenile stages. }\end{array}$ \\
\hline $\begin{array}{l}\text { Water quality } \\
\text { management }\end{array}$ & 44 & 27 & $\begin{array}{l}\text { Regulation of agricultural runoff and municipal waste discharge } \\
\text { will decrease exposure to endocrine-disrupting chemicals, thereby } \\
\text { decreasing incidence of reproductive impairments and increasing } \\
\text { reproductive success of adults. }\end{array}$ \\
\hline $\begin{array}{l}\text { Flow regime } \\
\text { Platte River }\end{array}$ & 50 & 28 & $\begin{array}{l}\text { Naturalization of flow regime on the Platte River (Nebraska), will } \\
\text { allow migration, spawning, and recruitment to the Missouri River } \\
\text { population. }\end{array}$ \\
\hline \multirow[b]{2}{*}{$\begin{array}{l}\text { Propagation } \\
\text { Lower Basin }\end{array}$} & 56 & 29 & $\begin{array}{l}\text { Stocking at optimal size classes will increase growth rates and } \\
\text { survival of exogenously feeding larvae and juveniles. }\end{array}$ \\
\hline & 58 & 30 & $\begin{array}{l}\text { Stocking of fish with appropriate genetic heritage and at river } \\
\text { locations with appropriate habitats will increase growth and } \\
\text { survival of exogenously feeding larvae and juveniles. }\end{array}$ \\
\hline
\end{tabular}

Concerted science efforts include the Pallid Sturgeon Population Assessment Project, the Habitat Assessment and Monitoring Project (HAMP), the Comprehensive Sturgeon Research Project, and early life-stage research carried out at the South Dakota State University. The current (2015) state of the considerable scientific information on pallid sturgeon has been compiled in two recent documents: (U.S. Fish and Wildlife Service, 2014; DeLonay and others, 2016). However, it should be noted that despite the large and increasing knowledge base on pallid sturgeon reproductive ecology, research has yet to prove one or more critical processes that are responsible for lack of population growth.

Our process of hypothesis formulation and filtering has been built on the foundation of previous work. Previous direction and prioritization of pallid sturgeon science have come from multiple sources including the Recovery Plan for the pallid sturgeon (U.S. Fish and Wildlife Service, 1993) and the revised plan (U.S. Fish and Wildlife Service, 2014), comprehensive workshops in 2004 and 2008 (Quist and others, 2004; Bergman and others, 2008), specific project reviews (Sustainable Ecosystems Institute, 2004, 2005, 2007, 2008), results of the "spring rise” plenary group process (Jacobson and Galat, 2008), and deliberations of the MRRIC ISAP (Doyle and others, 2011). 


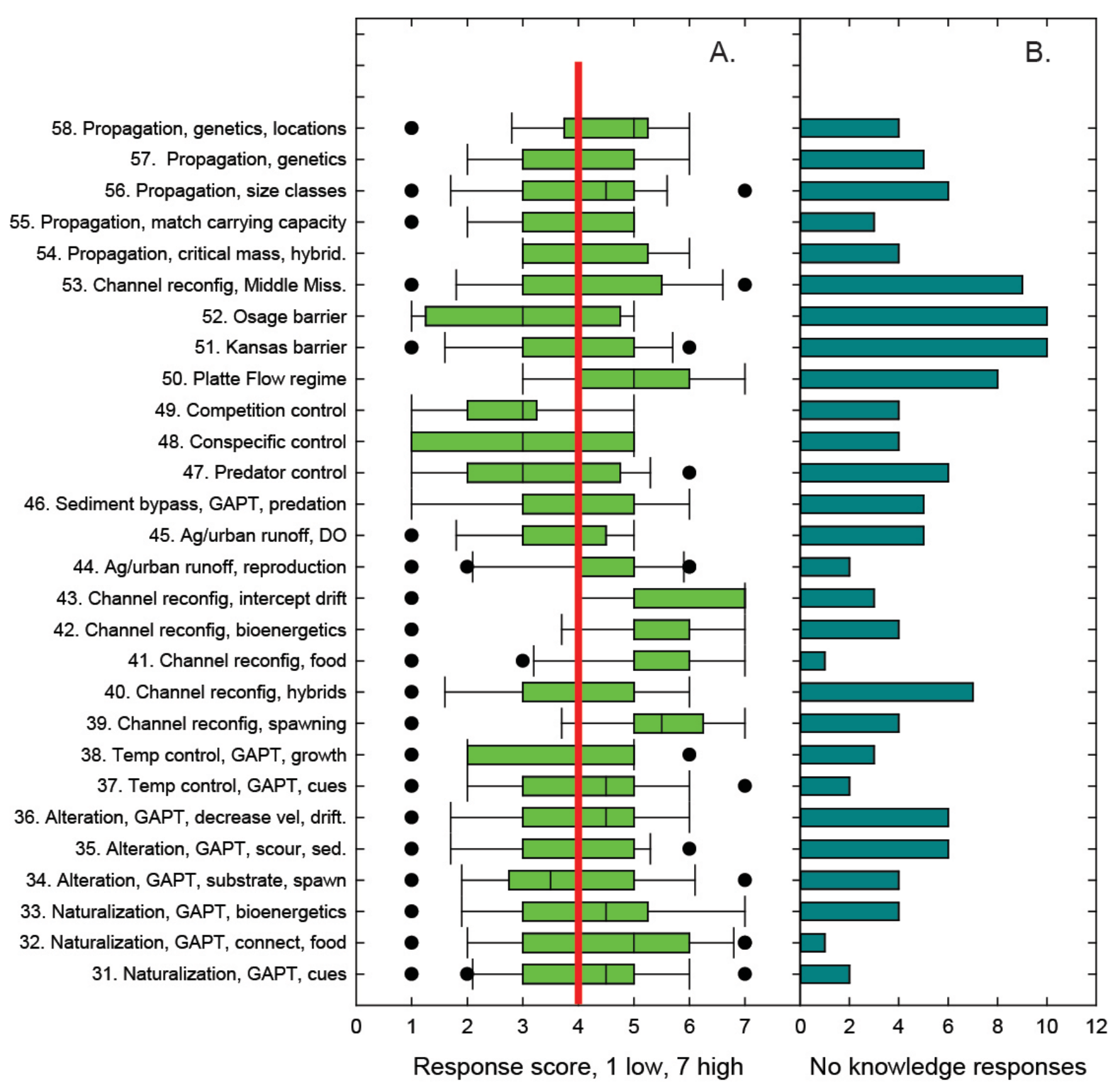

Figure 6. Graphs showing the results of the survey of working management hypotheses, Upper Missouri River. A, Response scores. B, No relevant knowledge. GAPT refers to the Gavins Point Dam; DO, dissolved oxygen.

These reports provided recommendations on broad areas of information that were lacking for pallid sturgeon recovery and those recommendations have been responsible for much of the direction of pallid sturgeon research from 2004 to the present (2015). However, these previous reports were not conceived in a framework that emphasized decision making under adaptive management, and therefore they did not develop specific hypotheses related to management actions and biotic responses as presented herein. 


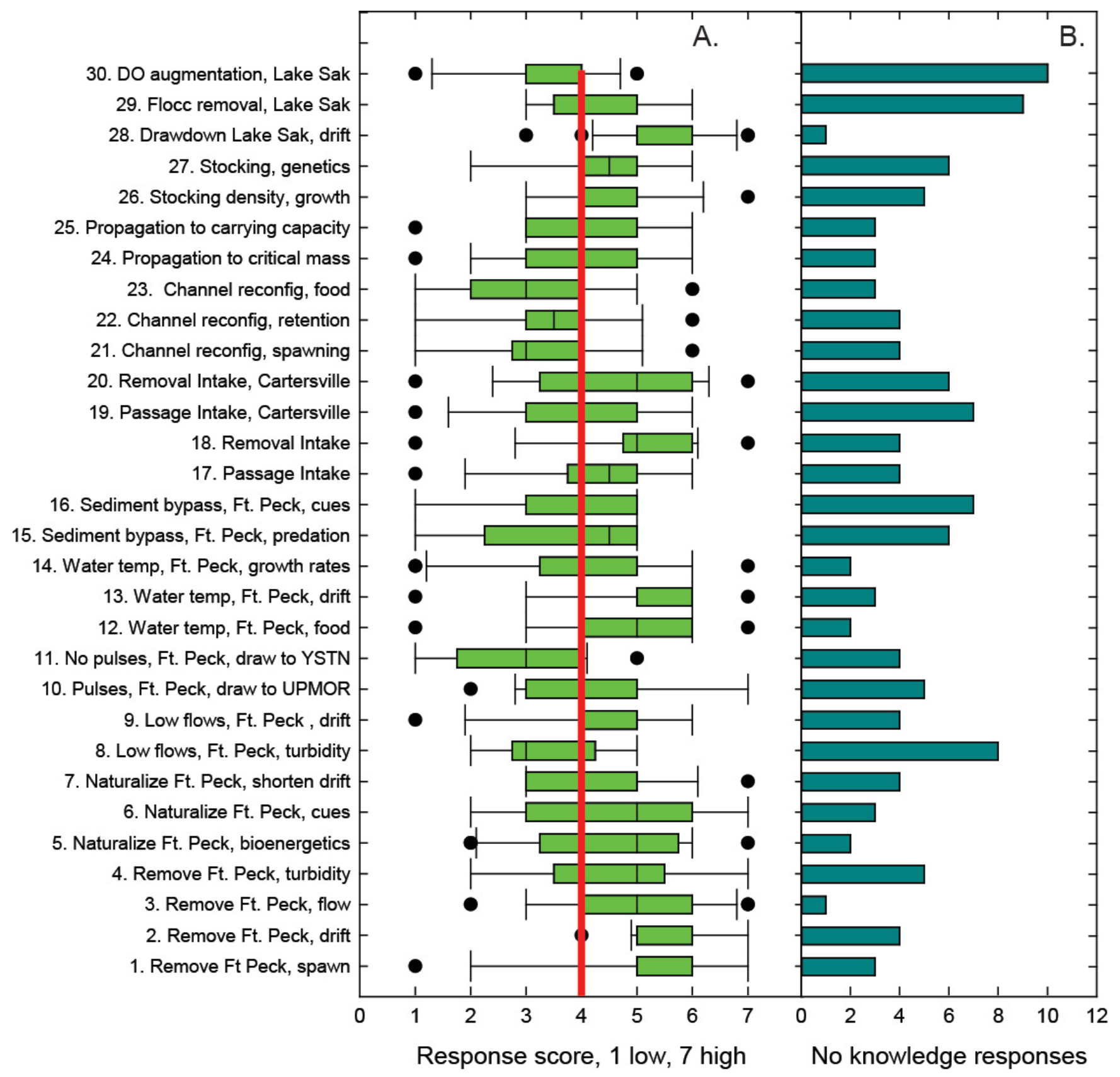

Figure 7. Graphs showing the results of the survey of working management hypotheses, Lower Missouri River. A, Response scores. B, No relevant knowledge. YSTN refers to the Yellowstone River and UPMOR refers to the Upper Missouri River; Lake Sak refers to Lake Sakakawea.

The focus needed to address management-relevant models necessarily requires filtering hypotheses down to an initial core set. In this filtering process, we have engaged a broad range of expert opinion and added their judgments to our own experience, judgment, and knowledge of the scientific literature. The result is a set of working management hypotheses to inform the quantitative modeling framework. 


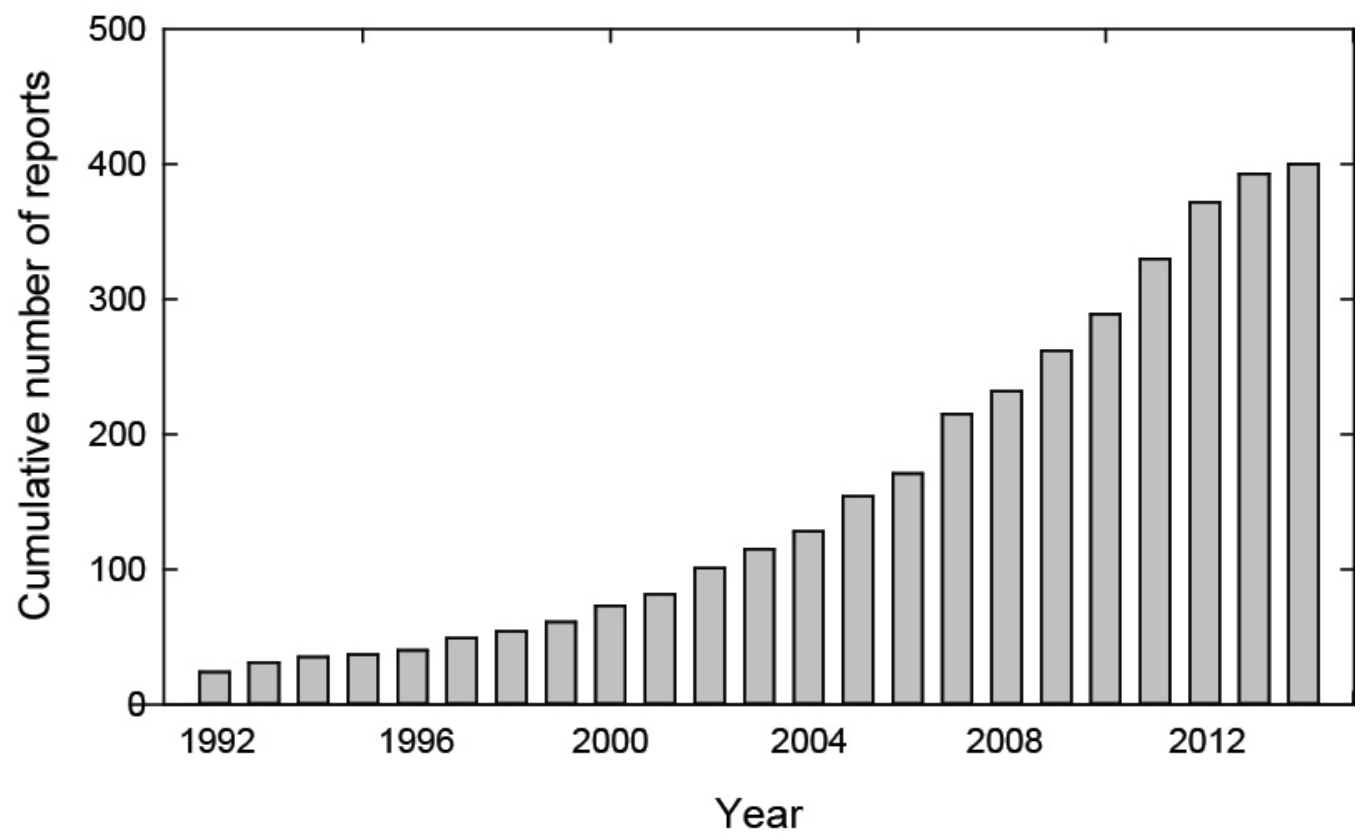

Figure 8. Cumulative growth in pallid sturgeon science peer-reviewed publications, 1992-2014.

The working management hypotheses developed and documented in this process are intended to be used in an adaptive management context. We anticipate, based on parallel development of the Adaptive Management Plan (A. Quinn, USACE, written commun., 2015), hypotheses, and the adaptive management process, will evolve to maintain the maximum relevance to Missouri River decision making. The following points are germane to how this initial set of management hypotheses will operate in the adaptive management context:

- Although we have filtered hypotheses to begin the modeling process, no hypothesis is ever "lost." Documentation of the hypotheses in this report and the CEM report (Jacobson and others, 2015b) serves to put them into a "hypothesis reserve" from which they can be resurrected at any time (fig. 1). This idea is fundamental to adaptive management—as new information comes available through systematic hypothesis testing in the course of management, hypotheses can be sequentially tested against the increasing information base, and if existing hypotheses are inadequate to explain observed behaviors, hypotheses can be resurrected from the reserve or created anew.

- The selection of hypotheses by this process is intended to define an initial, practical scope for development of quantitative models, but as quantitative models progress, we expect that the modeling results will begin to provide a quantitative basis for evolving, iterative hypothesis development. The expert-opinion based process we relied on in filtering for this report will be replaced progressively with quantitative model results that will indicate priority hypotheses. Because the component life-stage models are tied to a population-level model (Jacobson and others, 2015b), ongoing development of management hypotheses will be strongly governed by their mathematical leverage on population dynamics. 
- The quantitative models that will be developed to address the working management hypotheses will form a framework that will be useful for redesign and implementation of monitoring, assessment, and adaptive management on the Missouri River for pallid sturgeon recovery. The quantitative models will be available to identify critical information needs, such as model assumptions and uncertain model parameters, the metrics that will be most effective in evaluating system performance, and the information that will be most useful in decision making. The initial set of working management hypotheses is important because it serves to start the redesign of the modeling framework for the Missouri River adaptive management process. However, the initial seeding of hypotheses should progressively give way to more robust hypotheses. Approaches for utilizing new hypotheses and the reevaluation of reserved hypotheses will be determined in the Adaptive Management Plan that is currently (2015) being created.

\section{Summary and Conclusions}

This report documents a process of filtering of hypotheses that relate pallid sturgeon population dynamics of the Missouri River to management actions, including flow alterations, channel reconfigurations, and population augmentation. The process was part of the Missouri River Recovery Management Plan and undertaken as a partnership among U.S. Geological Survey, U.S. Army Corps of Engineers, and U.S. Fish and Wildlife Service. The objective of the filtering process was to produce an initial set of hypotheses linking management actions to pallid sturgeon population dynamics for application in Missouri River decision making. The filtered hypotheses will be used to determine the scope and nature of quantitative models required to guide adaptive management.

The process of filtering hypotheses started with conceptual ecological models (CEMs) that illustrated concepts of population dynamics at the population level and a series of component life-stage models that illustrated concepts relating survival of selected life stages to management actions, resulting ecological factors, and biotic responses. The CEMs were developed from workshops involving experts knowledgeable about pallid sturgeon biology and Missouri River processes throughout the upper and lower Missouri River Basin. Participants indicated hypothetical relations among management actions, ecological factors and biotic responses, based on perceived importance and uncertainty of the relations. The pathways drawn through the CEMs comprise the global set of hypotheses of every factor that was thought to plausibly affect pallid sturgeon population dynamics.

The Missouri River pallid sturgeon Effects Analysis (EA) team selected those relations in the global set that were of high importance to life-stage survival. These 40 hypotheses comprised a candidate set of dominant working hypotheses. The EA team compiled the candidate set from the CEMs and constructed a modified Delphi process to get expert opinion on their importance in explaining population dynamics. The Delphi process consisted of a Web-based survey, a workshop, and a followup Web-based survey. Twenty-three hypotheses that scored with medians above neutral were selected to move forward in the process. The EA team then matched the 23 hypotheses with management actions that could influence the biotic outcomes. Because there are multiple pathways through the CEMs, 176 potential linkages were identified. From those, the EA team consolidated linkages that applied to multiple life stages to define a candidate set of 53 working management hypotheses. We constructed another Web-based survey with a larger number of sturgeon and Missouri River experts to score the candidate set. Thirty of the 53 working management hypotheses had median scores above neutral and 
were selected to be filtered by the USACE for actions that were within the agency's authority and jurisdiction. This filtering by the USACE resulted in a set of 21 initially modeled hypotheses.

The filtered set of hypotheses provides a useful starting point for quantitative modeling of linkages between management actions and pallid sturgeon population dynamics on the Missouri River. The modeling structure developed to address these hypotheses in the EA is intended to be the framework for adaptive management of pallid sturgeon in the Missouri River, and following the concepts of adaptive management, it is meant to be flexible and accommodating of future information. More importantly, hypotheses that have been filtered out of the multi-step process illustrated here may be further considered. These hypotheses have been archived in this report and the CEM report (Jacobson and others, 2015b) and can be considered to be part of a hypothesis reserve. If existing hypotheses are determined to be inadequate to explain observed population dynamics, hypotheses are available to be resurrected from the reserve or created anew. The guidelines and approach for possible reevaluation of filtered hypothesis and (or) hypotheses refinement will be addressed in the Adaptive Management Report, which is under development. 


\section{References Cited}

Bergman, H.L., Boelter, A.M., Parady, K., Fleming, C., Keevin, T., Latka, D.C., Korschgen, C.E., Galat, D.L., Hill, T., Jordan, G., Krentz, S., Nelson-Stastny, W., Olson, M., Mestl, G., K., R., and Berkley, J., 2008, Research needs and management strategies for pallid sturgeon recovery.: in Second Pallid Sturgeon Workshop, University of Wyoming, Laramie, William D. Ruckelshaus Institute of Environment and Natural Resources, 36 p.

DeLonay, A.J., Chojnacki, K.A., Jacobson, R.B., Albers, J.L., Braaten, P.J., Bulliner, E.A., Elliott, C.M., Erwin, S.O., Fuller, D.B., Haas, J.D., Ladd, H.L.A., Mestl, G.E., Papoulias, D.M., and Wildhaber, M.L., 2016, Ecological requirements for pallid sturgeon reproduction and recruitment in the Missouri River-A synthesis of science, 2005 to 2012: U.S. Geological Survey Scientific Investigations Report 2015-5145, 224 p. with appendixes. [Also available at http://dx.doi.org/10.3133/sir20155145.]

DeLonay, A.J., Jacobson, R.B., Papoulias, D.M., Wildhaber, M.L., Chojnacki, K.A., Pherigo, E.K., Haas, J.D., and Mestl, G.E., 2012, Ecological requirements for pallid sturgeon reproduction and recruitment in the Lower Missouri River: Annual report 2010: U.S. Geological Survey OpenFile Report 2012-1009, 51 p.

Doyle, M., Murphy, D., Bartell, S., Farmer, A., Guy, C.S., Palmer, M., and Turner, R., 2011, Final report on spring pulses and adaptive management: Missouri River Recovery Program Independent Science Advisory Panel: U.S. Institute for Environmental Conflict Resolution, 58 p., [Also available at http://projects.ecr.gov/moriversciencepanel/pdfs/MRISAPFinalReportSpringPulseAdaptMgt113011.pdf.

Gregory, R., and Long, G., 2008, Summary and key findings of upper Columbia river white sturgeon recruitment failure hypothesis review: Upper Columbia River white sturgeon recovery initiative.

Jacobson, R.B., Annis, M.L., Parsley, M.J., James, D., Colvin, M.E., and Welker, T.L., 2015a, Scientific information to support the Missouri River pallid sturgeon effects analysis: U.S. Geological Survey Open-file Report 2015-1226, 88 p.

Jacobson, R.B., and Galat, D.L., 2008, Design of a naturalized flow regime-an example from the Lower Missouri River, U.S.A.: Ecohydrology, v. 1, no. 2, p. 81-104, [Also available at http://dx.doi.org/10.1002/eco.9.

Jacobson, R.B., Parsley, M.J., Annis, M.L., Colvin, M.E., Welker, T.L., and James, D., 2015b, Development of conceptual ecological models linking management of the Missouri River to pallid sturgeon population dynamics: U.S. Geological Survey Open-File Report 2015-1038, 47 p., [Also available at http://dx.doi.org/10.3133/ofr20151038].

Murphy, D.D., and Weiland, P.S., 2011, The route to best science in implementation of the Endangered Species Act's consultation mandate: The benefits of structured effects analysis: Environmental Management, v. 47, no. 2, p. 161-172, [Also available at http://www.ncbi.nlm.nih.gov/pubmed/21161526.

National Research Council Committee on Missouri River Ecosystem Science, 2002, The Missouri River ecosystems: exploring the prospects for recovery: Washington, D.C., The National Academies Press, 188 p. 
Normand, S.-L., McNeil, B.J., Peterson, L.E., and Palmer, R.H., 1998, Eliciting expert opinion using the Delphi technique: Identifying performance indicators for cardiovascular disease: International Journal for Quality in Health Care, v. 10, no. 3, p. 247-260, [Also available at http://dx.doi.org/10.1093/intqhc/10.3.247].

Parham, J.E., 2007, Hydrologic analysis of the lower Platte River from 1954-2004, with special emphasis on habitats of the endangered least tern, piping plover, and pallid sturgeon: Nebraska Game and Parks Commission, 186 p.

Quist, M.C., Boelter, A.M., Lovato, J.M., Korfanta, N.M., Bergman, H.L., Latka, D.C., Korschgen, C.E., Galat, D.L., Krentz, S., Oetker, M., Olson, M., Scott, C.M., and Berkley, J., 2004, Research and assessment needs for pallid sturgeon recovery in the Missouri River: Laramine, Wyo., 2004, U.S. Geological Survey, U.S. Army Corps of Engineers, U.S. Fish and Wildlife Service, U.S. Environmental Protection Agency, William D. Ruckelshaus Institute of Environment and Natural Resources, 96 p.

Rhoads, B.L., Wilson, D., Urban, M., and Herricks, E.E., 1999, Interaction between scientists and nonscientists in community-based watershed management: Emergence of the concept of stream naturalization: Environmental Management, v. 24, no. 3, p. 297-308, [Also available at http://dx.doi.org/10.1007/s002679900234.

Smith, C.B., 2011, Adaptive management on the central Platte River: Science, engineering, and decision analysis to assist in the recovery of four species: Journal of Environmental Management, v. 92, no. 5, p. 1414-1419, [Also available at http://www.ncbi.nlm.nih.gov/pubmed/20971546.

Sustainable Ecosystems Institute, 2004, Independent science review of the models and linkages for hydrological and biological processes of the Missouri River: Sustainable Ecosystems Institute, $23 \mathrm{p}$.

Sustainable Ecosystems Institute, 2005, Independent science review of the habitat assessment and monitoring program study plan for the Missouri River: Sustainable Ecosystems Institute, 39 p.

Sustainable Ecosystems Institute, 2007, Independent science review of the models and linkages for hydrological and biological processes of the Missouri River: Sustainable Ecosystems Institute, $23 \mathrm{p}$.

Sustainable Ecosystems Institute, 2008, Review of comprehensive sturgeon research program: Sustainable Ecosystems Institute, 49 p.

U.S. Army Corps of Engineers, 1981, Missouri River bank stabilization and navigation project final feasibility report and final EIS for the fish and wildlife mitigation plan: U.S. Army Corps of Engineers, Northwest Division.

U.S. Army Corps of Engineers, 2001, Summary Missouri River Revised Draft Environmental Impact Statement: Master Water Control Manual Review and Update: U.S. Army Corps of Engineers, $28 \mathrm{p}$.

U.S. Army Corps of Engineers, 2006, Missouri River Mainstem Reservoir System: Master Water Control Manual, Missouri River Basin: U.S. Army Corps of Engineers, Northwest Division, 431 p.

U.S. Fish and Wildlife Service, 1993, Recovery plan for the pallid sturgeon (Scaphirhynchus albus): Endangered Species Bulletins and Technical Reports (USFWS).

U.S. Fish and Wildlife Service, 2000a, Biological opinion for the operation and maintenance of the 9foot navigation channel on the upper Mississippi River system: U.S. Fish and Wildlife Service, 244 p. 
U.S. Fish and Wildlife Service, 2000b, Biological opinion on the operation of the Missouri River main stem reservoir system, operation and maintenance of the Missouri River bank stabilization and navigation project, and operation of the Kansas River reservoir system: U.S. Fish and Wildlife Service, 296 p.

U.S. Fish and Wildlife Service, 2003, Amendment to the 2000 biological opinion on the operation of the Missouri River main stem reservoir system, operation and maintenance of the Missouri River bank stabilization and navigation project, and operation of the Kansas River reservoir system: U.S. Army Corps of Engineers, 12 p.

U.S. Fish and Wildlife Service, 2014, Revised recovery plan for the pallid sturgeon (Scaphirhynchus albus): U.S. Fish and Wildlife Service, 115 p. 